\title{
Metamorphosed cumulate gabbros from the Støren Group of the Upper Allochthon, northern Western Gneiss Region, Norway: petrology and metamorphic record
}

\author{
Kurt Hollocher, Peter Robinson, Colleen Kennedy \& Emily Walsh
}

Hollocher, K., Robinson, P., Kennedy, C. \& Walsh, E.: Metamorphosed cumulate gabbros from the Støren Group of the Upper Allochthon, northern Western Gneiss Region, Norway: petrology and metamorphic record. Norwegian Journal of Geology, Vol 94, pp. 283-303.

\begin{abstract}
The Støren Group of the Upper Allochthon, in the Scandinavian Caledonides, contains Late Cambrian to Early Ordovician ophiolitic fragments that developed in a tholeiitic oceanic suprasubduction zone setting. These were obducted onto an epicontinental margin (Gula Complex) in the Early Ordovician, and metamorphosed in most areas to greenschist facies. Later, these rocks were thrust onto Baltica as part of the Upper Allochthon during the Silurian-Devonian Scandian Orogeny. Cumulate gabbros in the Støren Group contain the prograde metamorphic assemblage amphibole-plagioclase-diopside-epidote. They have complex textures that include early metamorphic mineral cores and inclusions, later rims, and late vein assemblages. The textures and mineral compositions in nine samples were interpreted iteratively with Perple_X thermodynamic modeling, to reveal three sequential P-T conditions: $\sim 350^{\circ} \mathrm{C}$ and $\sim 6 \mathrm{kbars}$ for early prograde mineral cores and inclusions, $\sim 530^{\circ} \mathrm{C}$ and $\sim 6 \mathrm{kbars}$ for peak prograde conditions, and $\sim 425^{\circ} \mathrm{C}$ and $\sim 3 \mathrm{kbars}$ for an early retrograde vein assemblage. Additionally, minor but ubiquitous, discontinuous $\mathrm{Fe}^{3+}-$ rich rims on epidote suggest the rocks underwent isothermal decompression immediately after peak prograde conditions, crossing increasingly Fe-rich epidote isopleths predicted by models. We interpret a single-episode, clockwise P-T path representing an Early Devonian phase of Scandian metamorphism. In the study area, prograde metamorphism produced these assemblages only in rocks close to the contact between the Upper and Middle allochthons, which is interpreted as a late-Scandian detachment fault (Agdenes detachment). Prograde Scandian metamorphism of this part of the Upper Allochthon was a form of contact metamorphism, occurring as the detachment fault juxtaposed cool Upper Allochthon rocks against the hotter, exhuming Middle Allochthon.
\end{abstract}

Kurt Hollocher, Department of Geology, Union College, Schenectady, New York 12308, USA. Peter Robinson, Norges geologiske undersøkelse, 7491 Trondheim, Norway. Colleen Kennedy, Geotesting Express, 125 Nagog Park, Acton MA, 01720, USA. Emily Walsh, Department of Geology, Cornell College, Mount Vernon, Iowa 52314, USA.

E-mail corresponding author (Kurt Hollocher): hollochk@union.edu

Published online: 30. April, 2015.

This work is licensed under a Creative Commons Attribution 4.0 International License.

\section{Introduction}

\section{Geologic setting}

The Scandinavian Caledonides is an assemblage of thrust sheets that were ultimately transported onto the Baltican margin during the Silurian-Early Devonian Scandian collision between Baltica and Laurentia. The thrust sheets include the distal Baltican margin and a nearby Early Paleozoic arc (Lower and Middle allochthons), oceanic arc complexes within Iapetus (Upper Allochthon), and parts of the Laurentian margin (Uppermost Allochthon; e.g., Gee, 1975, 2005; Roberts et al., 1985, 2007; Stephens \& Gee, 1985; Roberts, 2003; Barnes et al., 2007; Gee et al., 2008). In the study area, the Upper Allochthon can be divided into four major parts:

Part (1) is the 500-480 Ma Støren Group, composed largely of mafic oceanic arc and back-arc volcanic and plutonic assemblages that include ophiolites. These were obducted onto an epicontinental margin, now the Gula Complex (part 2) at 480-475 Ma (e.g., Furnes et al., 1988; Sturt \& Roberts, 1991; Roberts, 2003). Metamorphism during obduction is not well constrained because of Scandian overprinting, but at one location it reached lower blueschist facies conditions (Eide \& Lardeaux, 2002, western Bymarka ophiolite, Fig. 1). In another location, hornblende and biotite preserve Early Ordovician ${ }^{40} \mathrm{Ar}-{ }^{39} \mathrm{Ar}$ ages (Dallmeyer et al., 1985, Tännforsen area). Relatively undeformed greenschist-facies rocks, some containing relict igneous augite, are found in the Løkken area and extensively elsewhere. From during to well after obduction of the Støren Group, a 477-441 Ma (Tucker et al., 2004) calc-alkaline arc (part 3) developed, built at least in part on the Støren Group. The plutonic roots of this arc are exposed to the north and west of Trondheim near the coast (Fig. 1). In the back-arc region, to the northeast, east, and southwest of Trondheim, Late Arenig 


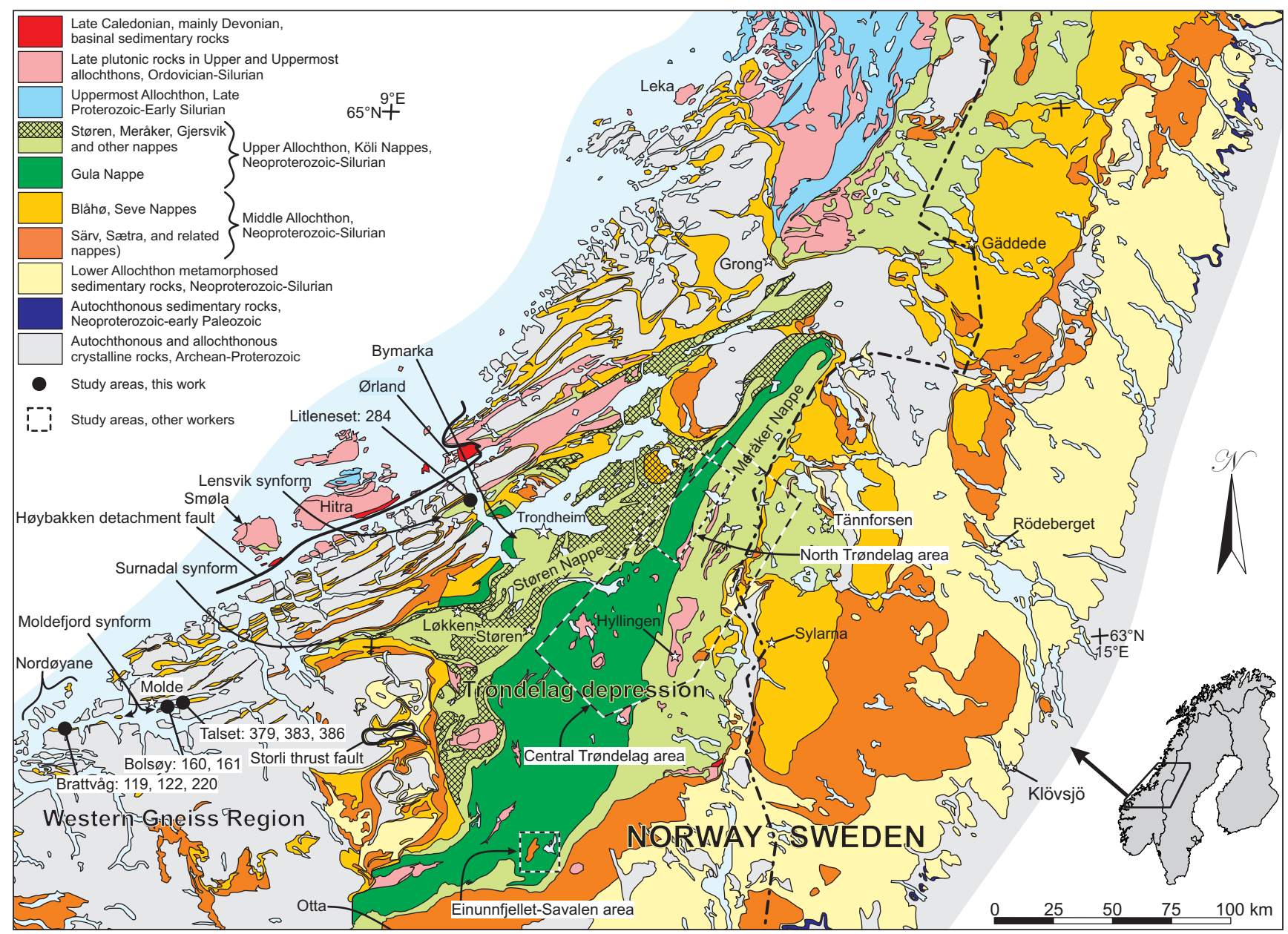

Figure 1. Map of the central Scandinavian Caledonides, showing nappes and study areas for this work and for other workers. Modified after Hollocher et al. (2012). The cross-hatched parts of the Støren Nappe show the Lower and Upper Hovin groups and related units. The Agdenes detachment (Robinson et al., 2014), of key importance in understanding the metamorphism of rocks discussed here, is defined as the base of the Upper Allochthon. Sample numbers and locations are shown.

and younger metamorphosed sedimentary and volcanic rocks of the Lower Hovin Group and related units (part 4) were deposited unconformably on the Støren Group. (Grenne \& Roberts, 1980; Grenne et al., 1980; Bjerkgård \& Biørlykke, 1994; Roberts \& Tucker, 1998; Roberts et al., 2002; Tucker et al., 2004; Bingen \& Solli, 2009). The Upper Allochthon package was thrust onto Baltica during the Silurian-earliest Devonian Scandian collision.

The rocks we discuss are in the Støren Group (part 1) of the Upper Allochthon. Scandian metamorphism in the Upper Allochthon was generally greenschist facies, but up to amphibolite facies particularly near contacts with the underlying Middle Allochthon. Robinson et al. (2014), working in central Norway, interpreted this pattern to indicate that the highest metamorphic grades developed in the Upper Allochthon during detachment faulting toward the end of Scandian orogenesis. Our goals in this study were: (1) to characterize the metamorphic history of the rocks using mineral compositions, textures, and thermodynamic modeling, and (2) to place the timing of metamorphism into the tectonic framework generally worked out for the Upper Allochthon.

\section{Metamorphism in the central Caledonide Upper Allochthon}

Different thrust sheets in the Scandinavian Caledonides experienced different metamorphic histories prior to final Scandian emplacement, locally resulting in inverted isograds and discontinuities in metamorphic grade across thrust faults (Andréasson \& Gorbatschev, 1980; Bryhni \& Andréasson, 1985; Lindqvist \& Andreasson, 1987). Abundant descriptive petrographic work has been done on mafic rocks in the Upper Allochthon (e.g., Grenne \& Roberts, 1980; Roberts, 1982; Heim et al., 1987; Furnes et al., 1988; Bjerkgård \& Bjørlykke, 1994; Hollocher et al., 2012). In general, the mafic rocks are described as greenstones, greenschists, and amphibolites. In both the Trondheim area and farther east in Jämtland, Sweden, mafic rocks commonly have the assemblage hornblende-plagioclase-epidote \pm chlorite, carbonate, and biotite, or actinolite-chlorite-epidote \pm carbonate, albite, and white mica.

In the recent literature, most detailed petrographic work and P-T (pressure-temperature) calculations have been on eclogite and ultramafic rocks, which occur in deeply subducted parts of the Lower and Middle allochthons 
(e.g., Chauvet et al., 1992; Andréasson \& Albrecht, 1995; Cuthbert et al., 2000; Terry et al., 2000; Walsh \& Hacker, 2004; Root et al., 2005; Peterman et al., 2009). Petrologic work that includes the Upper Allochthon in the area of Fig. 1 has concentrated on pelitic assemblages, for example McClellan (2004) in the Einunnfjellet-Savalen area, and Hacker \& Gans (2005) in the central Trøndelag area. Those workers generally found that the rocks experienced peak metamorphic conditions of biotite to kyanite grades. Pelitic rocks are extremely rare in the Støren Group in the area we discuss, so we concentrated on mafic rocks.

\section{Sample set and analytical methods}

In the study area (Fig. 1), the rocks are mostly monotonous greenish-gray, fine-grained, layered, strongly foliated and lineated greenschists and epidote amphibolites that are interpreted to be metamorphosed basaltic volcanics. Much less abundant are andesitic, dacitic, and rhyolitic volcanic rocks, and thin marbles. Coarse-grained metamorphosed gabbroic rocks, from which our samples were collected, occur as a laterally extensive unit 16 to $33 \mathrm{~m}$ thick in the Moldefjord synform (Robinson, 1995; Hollocher et al., 2012), and as incompletely mapped bodies at Litleneset and elsewhere. We selected gabbroic rocks with apparent cumulate protoliths for petrographic work because they lacked chlorite. We presumed that chlorite would have reequilibrated easily, complicating thermobarometric interpretation. Our set of nine metamorphosed gabbro samples came from three areas in the Moldefjord synform and one in the Lensvik synform at Litleneset in the northern Western Gneiss Region (Fig. 1; 'Støren gabbro' of Hollocher et al., 2012). The samples were all collected 60-135 m (map distance) from the base of the Upper Allochthon, which has been interpreted to be part of the Agdenes detachment fault (Robinson et al., 2014).

In some areas the metamorphosed gabbros appear homogeneous on a meter scale or greater, but elsewhere there are alternating feldspar-rich and mafic-rich layers, including modally graded layers, ranging in thickness from one to tens of centimeters (Fig. 2). The present thickness of the gabbro layers is certainly not primary, but reflects thinning related to late orogen-parallel strain to which these rocks were subjected, at least partly during active movement along the Agdenes detachment fault and later subhorizontal sinistral shear (Robinson, 1995, Robinson et al., 2014). In addition to being more coarse grained than nearby mafic volcanic rocks, the gabbro samples are also more $\mathrm{MgO}$ - and $\mathrm{CaO}$-rich, with median values of $10.8 \% \mathrm{MgO}$ and $14.2 \% \mathrm{CaO}$ compared to $8.3 \% \mathrm{MgO}$ and $11.2 \% \mathrm{CaO}$ in associated volcanics (see Hollocher et al., 2012, for complete rock compositions, locations, and descriptions).

Polished thin-sections were made of all nine cumulate gabbro samples discussed here. These were examined

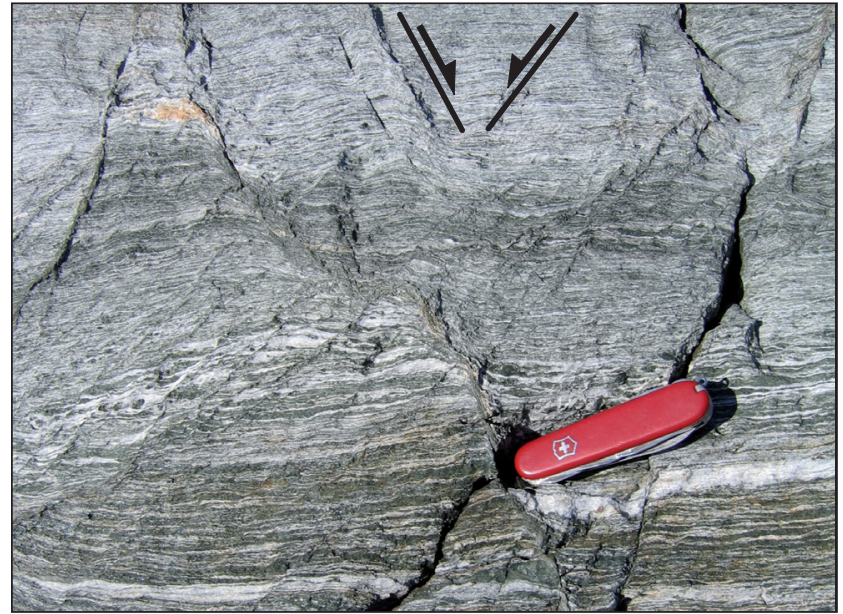

Figure 2. Outcrop photograph of metamorphosed, coarse-grained, layered gabbro near Brattvag, near the location of samples 119 and 122. A strong subhorizontal lineation is parallel to the outcrop surface. Asymmetric tails on plagioclase and hornblende porphyroclasts indicate typical sinistral shear along the lineation. Notice the transitional ductilebrittle conjugate normal shear zones that cross diagonally through the rock, approximately parallel to the black lines and arrows.

using transmitted and reflected polarized light microscopy and, after carbon coating, with backscattered electron imaging. Minerals were analyzed by standardsbased SEM-EDX spectroscopy (Appendix 1). Thermodynamic modeling was done using Perple_X (Connolly, 2009; Appendix 2). Mineral analyses are given in Electronic Supplement 1.

\section{Petrography and crystal chemistry}

The analyzed samples all have an assemblage, in decreasing order of mineral abundance, of plagioclaseamphibole-epidote-diopside-titanite \pm pyrite, chalcopyrite, pyrrhotite, and calcite. Plagioclase, amphibole, and epidote are strongly zoned, and diopside is moderately zoned. No rutile occurs in the samples described here, but some associated gabbroic rocks have titanite rimming rutile, or titanite in apparent textural equilibrium with rutile.

\section{Amphiboles}

Fig. $3 \mathrm{~A}$ shows a typical large amphibole grain that is zoned from a light-colored actinolite core to an optically continuous, darker (green) hornblende rim. In the backscattered electron image (Fig. 3B), the rim is lighter than the core because of higher total iron content. The actinolite cores commonly contain inclusions of epidote, plagioclase, diopside, and calcite, preserving part of an early metamorphic assemblage. The transition between actinolite cores and hornblende rims is gradual over $10-50 \mu \mathrm{m}$ in some grains, and narrow enough to yield a Becke line in others. Many grains have both sharp and gradational transitions. X-ray emission profiles run at 5 


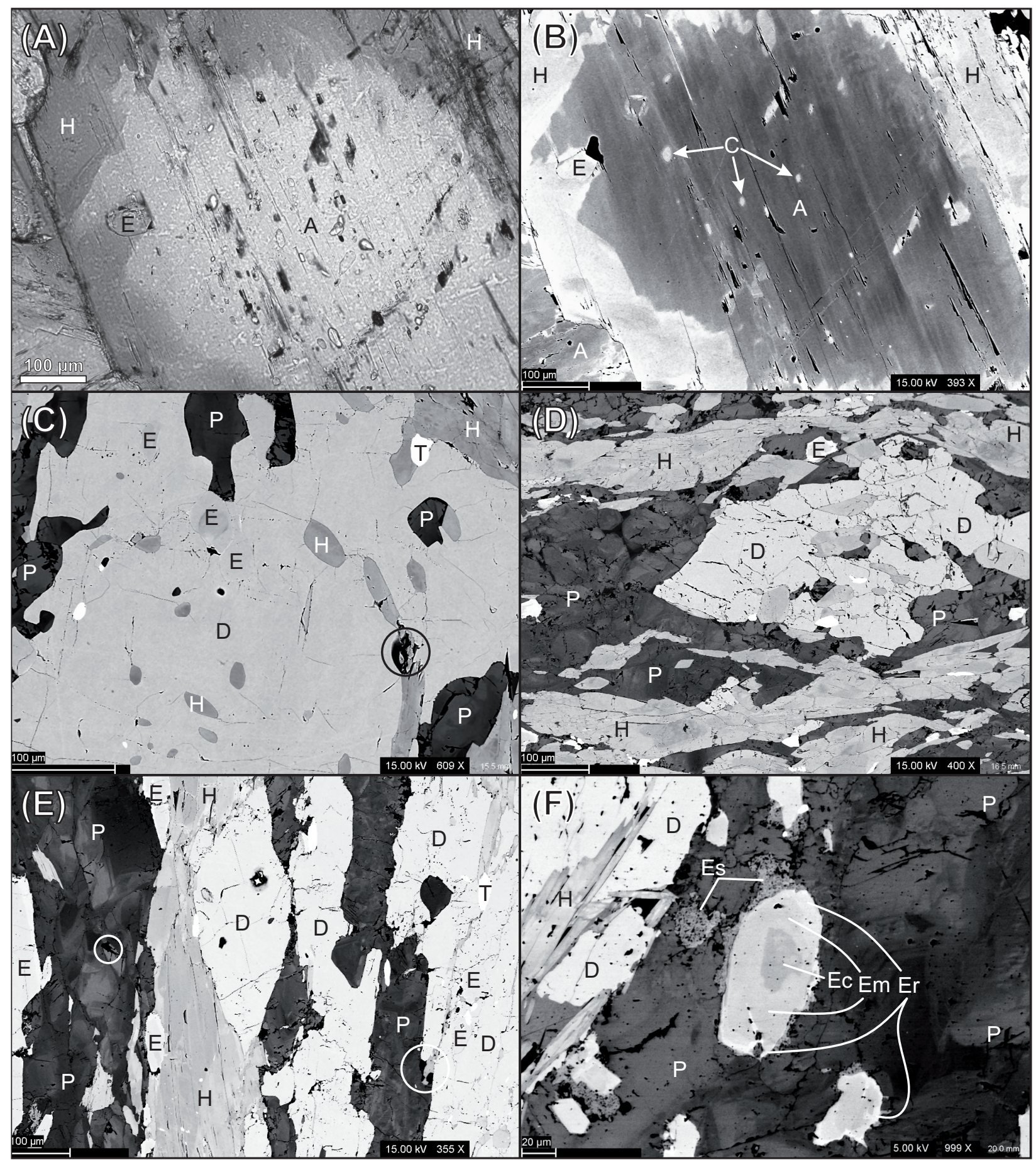

Figure 3. Plane-polarized light $(A)$ and backscattered electron images $(B-F)$ of representative regions where minerals were analyzed. $(A, B)$ Sample 386: actinolite core to peak prograde hornblende rim, showing inclusions that, with host actinolite, were part of the early prograde metamorphic assemblage. (C) Sample 379: diopside grain containing inclusions of epidote, amphibole, and plagioclase. Circled area contains late retrograde chlorite. (D) Sample 386: a typical amphibole-diopside-plagioclase-epidote assemblage. Note the zoning in both matrix plagioclase (An49-83), epidote (0.36 Fe ${ }^{3+}$ per formula unit in mantles to 0.58 in rims), and amphibole (1.4-8.8\% $\mathrm{Al}_{2} \mathrm{O}_{3}, \mathrm{Mg}^{\prime}$ 83-72). (E) Sample 220: a typical analyzed assemblage with zoned matrix plagioclase (An40-85), epidote (0.26 Fe ${ }^{3+}$ cores, 0.36 in mantles, to 0.72 in rims), and amphibole (1.1-9.7\% Al $\mathrm{O}^{3}, \mathrm{Mg}$ ' 81-67). Left circled area has retrograde plagioclase (An15), right circled area has retrograde albite (An2) and calcite (Mg, Mn, Fe components $<1$ molar \% each). (F) Sample 220: the four epidote types: low-Fe cores (Ec), intermediate Fe mantles (Em), discontinuous Fe-rich rims (Er), and low-Fe spongy epidote (Es). Other abbreviations: $A$ - actinolite, $C$ - calcite inclusions, $D$ - diopside, $E$ - epidote, $H$ - hornblende and actinolite, $P$ - plagioclase, $T$ - titanite.

$\mathrm{keV}(\sim 0.5 \mu \mathrm{m}$ resolution, not shown) indicate that the zoning transition for aluminum occurs over $\sim 2 \mu \mathrm{m}$ on the sharpest contacts. We saw no conclusive evidence for the equilibrium coexistence of two amphiboles in these rocks, such as exsolution lamellae or discrete, adjacent actinolite and hornblende crystals (e.g., Klein, 1969; 
Brady, 1974; Choudhuri, 1974; Grapes, 1975; Semelik et al., 1991; Schumacher, 2007). We interpret the gradual transitions between actinolite and hornblende to result from continuous prograde growth during a single metamorphic episode. We interpret the sharp transitions as dissolution surfaces that formed during deformationinduced recrystallization, with subsequent hornblende overgrowth.

Estimation of the $\mathrm{Fe}^{3+}$ content of amphiboles from electron beam analyses is a long-standing problem (e.g., Robinson \& Jaffe, 1969; Robinson et al., 1982; J.C. Schumacher, 1991). Here, $\mathrm{Fe}^{3+}$ estimates were based on the method of Holland \& Blundy (1994), in which the minimum and maximum $\mathrm{Fe}^{3+}$ permitted by 'lower bound' and 'upper bound' constraints, are averaged to yield the amphibole $\mathrm{Fe}^{3+}$ estimate. For actinolite the minimum and maximum $\mathrm{Fe}^{3+}$ limits were the $15 \mathrm{eK}$ and $15 \mathrm{eNaK}$ schemes, respectively (terminology of J.C. Schumacher, 1991; Holland and Blundy, 1994, normalizations 7 and 3 ). For hornblende the equivalents were the $13 \mathrm{eCaNaK}$ and $15 \mathrm{eNaK}$ schemes (normalizations 8 and 3). None of the other seven schemes outlined by Holland \& Blundy (1994) yielded valid amphibole formulae. These $\mathrm{Fe}^{3+}$ estimation methods yielded results similar to the method of R. Schumacher (1991), which was designed for epidoteand diopside-bearing amphibolites at somewhat higher grade than those of this study. Among our samples, average $\mathrm{Fe}^{3+} / \mathrm{Fe}_{\text {total }}$ for hornblende (>1 Al per formula unit) and actinolite $(<0.5 \mathrm{Al}$ per formula unit) was 0.28 and 0.17 , respectively. The average $\mathrm{Fe}^{3+}$ content of hornblende was always greater than actinolite in the same sample. These data were used to classify the amphiboles using Leake et al. (1997; Fig. 4), which shows a general trend from magnesian actinolite to magnesiohornblende (hereafter hornblende), with generally decreasing $\mathrm{Mg}$ ' values $\left(100 * \mathrm{Mg} /\left(\mathrm{Mg}+\mathrm{Fe}^{2+}\right)\right)$ in that sequence.

Relations between major substitutions in the amphiboles, other than $\mathrm{Mg}$ and $\mathrm{Fe}^{2+}$, are shown in a plot of $\mathrm{Na}+\mathrm{K}$ in the A site vs. tetrahedral $\mathrm{Al}$ (Fig. 5A). From tremolite and actinolite, the major substitutions are $\square^{\mathrm{A}}+\mathrm{Si}^{\mathrm{iV}} \leftrightarrow(\mathrm{Na}+\mathrm{K})^{\mathrm{A}}$ $+\mathrm{Al}^{\mathrm{IV}}$ toward edenite, and $\left(\mathrm{Mg}, \mathrm{Fe}^{2+}\right)^{\mathrm{VI}}+\mathrm{Si}^{\mathrm{iV}} \leftrightarrow\left(\mathrm{Al}+\mathrm{Fe}^{3+}\right)^{\mathrm{VI}}$ $+\mathrm{Al}^{\mathrm{IV}}$ toward tschermakite, with the line to pargasite intermediate between the two. Fig. 5A shows the amphibole data extending away from the tremolite-actinolite corner toward compositions intermediate between pargasite and tschermakite. Actinolite cores and inclusions having $<0.5$ $\mathrm{Al}$ per formula unit $(\mathrm{n}=32)$ have an average of $0.02 \mathrm{Na}$ + K per formula unit (65\% in the A-site, $35 \%$ in M4) and $0.25 \mathrm{Al}$ (19\% octahedral, 81\% tetrahedral). Green hornblende mantles and rims having $>1 \mathrm{Al}$ per formula unit $(\mathrm{n}$ $=48)$ have an average of $0.26 \mathrm{Na}+\mathrm{K}(91 \%$ in A-sites, $8 \%$ in M4) and $1.35 \mathrm{Al}$ (27\% octahedral, $73 \%$ tetrahedral). Fig. 5B shows that actinolite has Mg' values of 81-92 (average 85), whereas hornblende rims tend to be more Fe-rich, with $\mathrm{Mg}$ values of 73-87 (average 78; also Fig. 4). A likely explanation for this is that $\mathrm{R}^{3+}$ ions tend to replace $\mathrm{Mg}$ in $\mathrm{M} 2$ sites, reducing $\mathrm{Mg}$.

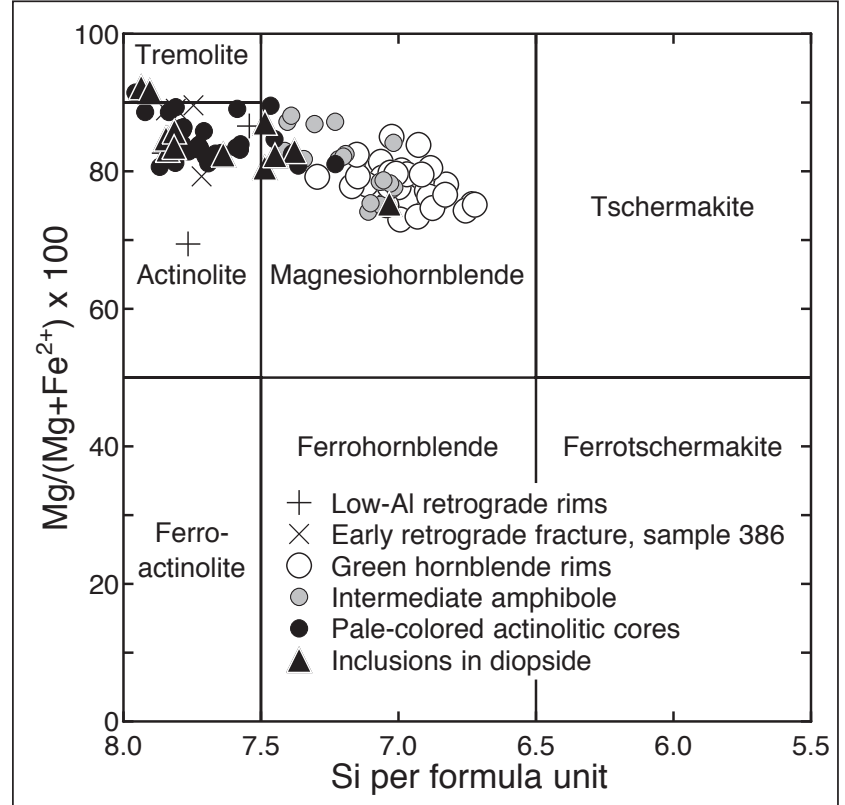

Figure 4. Amphibole classification diagram of Leake et al. (1997), showing all amphibole analyses. This diagram is for calcic amphiboles having $<0.5 \mathrm{Na}+\mathrm{K}$ in the A-site, which includes all of ours. Analyses include $\mathrm{Fe}^{3+}$ estimates (see text).

\section{Diopside}

Fig. 3C-F show typical diopside grains, which include and are surrounded by grains of zoned amphibole, plagioclase, and epidote. Diopside in all samples is almost unzoned with respect to $\mathrm{Fe}$ and $\mathrm{Mg}$, and among all samples it has a narrow range of $\mathrm{Mg}$ ' values (Fig. 5C). Diopside has minor amounts of $\mathrm{Na}$ (up to $0.4 \% \mathrm{Na}_{2} \mathrm{O}$ ) and $\mathrm{Al}$ (up to $1.9 \% \mathrm{Al}_{2} \mathrm{O}_{3}$ ), but variations in mean atomic number were too small to show up in backscattered electron images, except rare, thin, Fe-rich rims. Though $\mathrm{Na}$ and $\mathrm{Al}$ are positively correlated (not shown), paralleling the same elements in amphiboles (Fig. 5A), Na and $\mathrm{Al}$ zoning in diopside in all samples seems to be irregular, more like plagioclase (see below) than the amphiboles.

\section{Epidote}

Among the nine samples, epidote has a range of 0.06$0.74 \mathrm{Fe}^{3+}$ per 12.5 oxygen formula unit, which includes clinozoisite and epidote (classification of Armbruster et al., 2006; assuming all $\mathrm{Fe}$ is $\mathrm{Fe}^{3+}$; Fig. 5D, all referred to here as epidote). Epidote in individual samples can have as many as four distinct compositional parts: (1) relatively rare Fe-poor cores, (2) broad, nearly homogeneous mantles that have sharp to gradational contacts with cores, (3) discontinuous and typically irregular Fe-rich rims having sharp contacts with the mantles, and (4) late spongy epidote (Fig. 3F). Epidote inclusions in actinolite and diopside have a range of $0.06-0.36 \mathrm{Fe}^{3+}$ per formula unit, compared to $0.16-0.37$ for the $\mathrm{Fe}$-poor epidote cores. Epidote mantles have a range of $0.34-0.48$, and Fe-rich rims have a range of $0.38-0.74$. In all samples, epidote $\mathrm{Fe}^{3+}$ content increases from core to mantle to rim. 

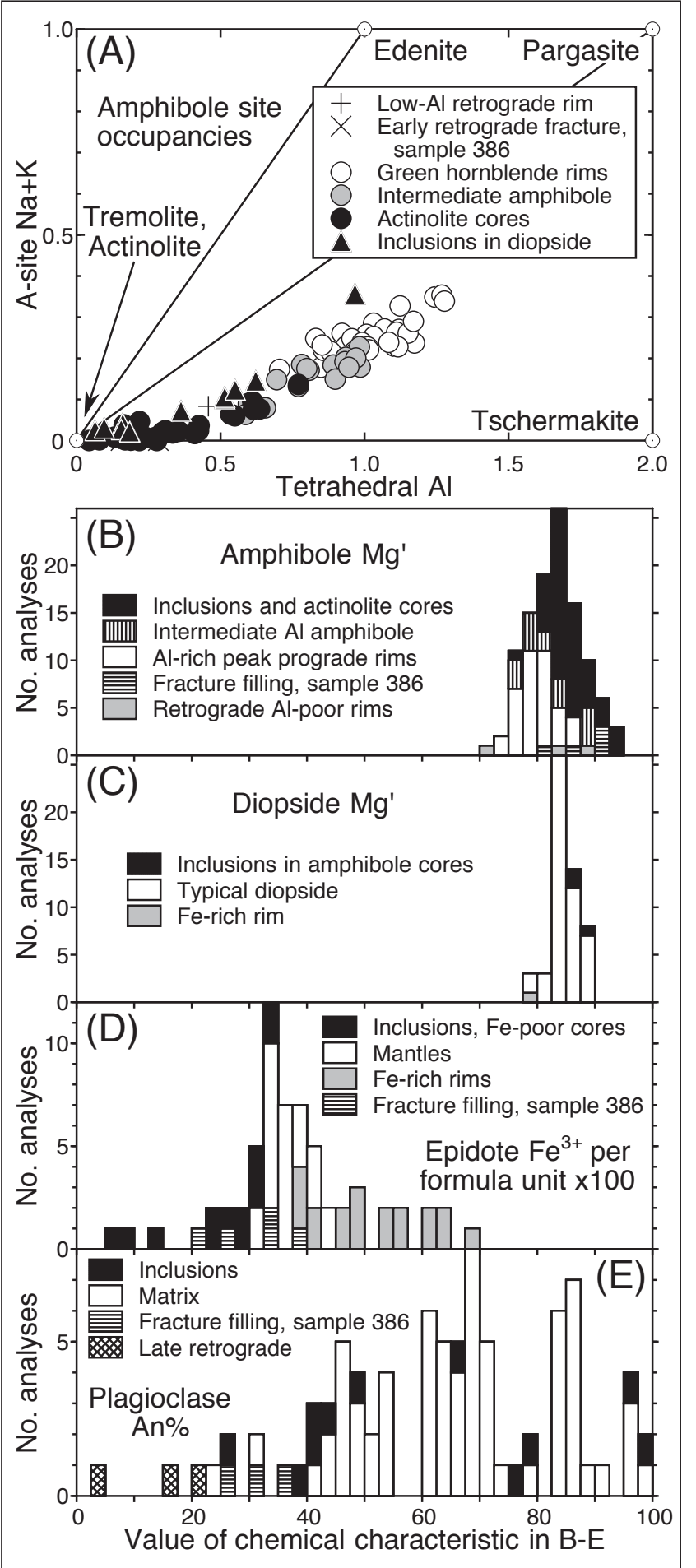

Figure 5. Graphs showing compositional characteristics for different petrologic parts of major minerals in all nine samples. (A) Amphibole A-site occupancy vs. tetrahedral Al. (B) Amphibole Mg. (C) Diopside $\mathrm{Mg}^{\prime}$. (D) Epidote $\mathrm{Fe}^{3+}$ per formula unit. (E) Plagioclase An\%. Histogram bar widths are $2.5 \%$ of the $X$-axis scales. The different mineral parts (rims, inclusions, etc.) are discussed in the text, and most are shown in Figs. $3 \& 6$.

Analyses of the apparently porous, spongy epidote indicate approximately $0.05 \mathrm{Fe}^{3+}$ per formula unit.

Particularly in regionally metamorphosed mafic rocks, epidote is typically $\mathrm{Fe}^{3+}$-rich in pumpellyite-actinolite

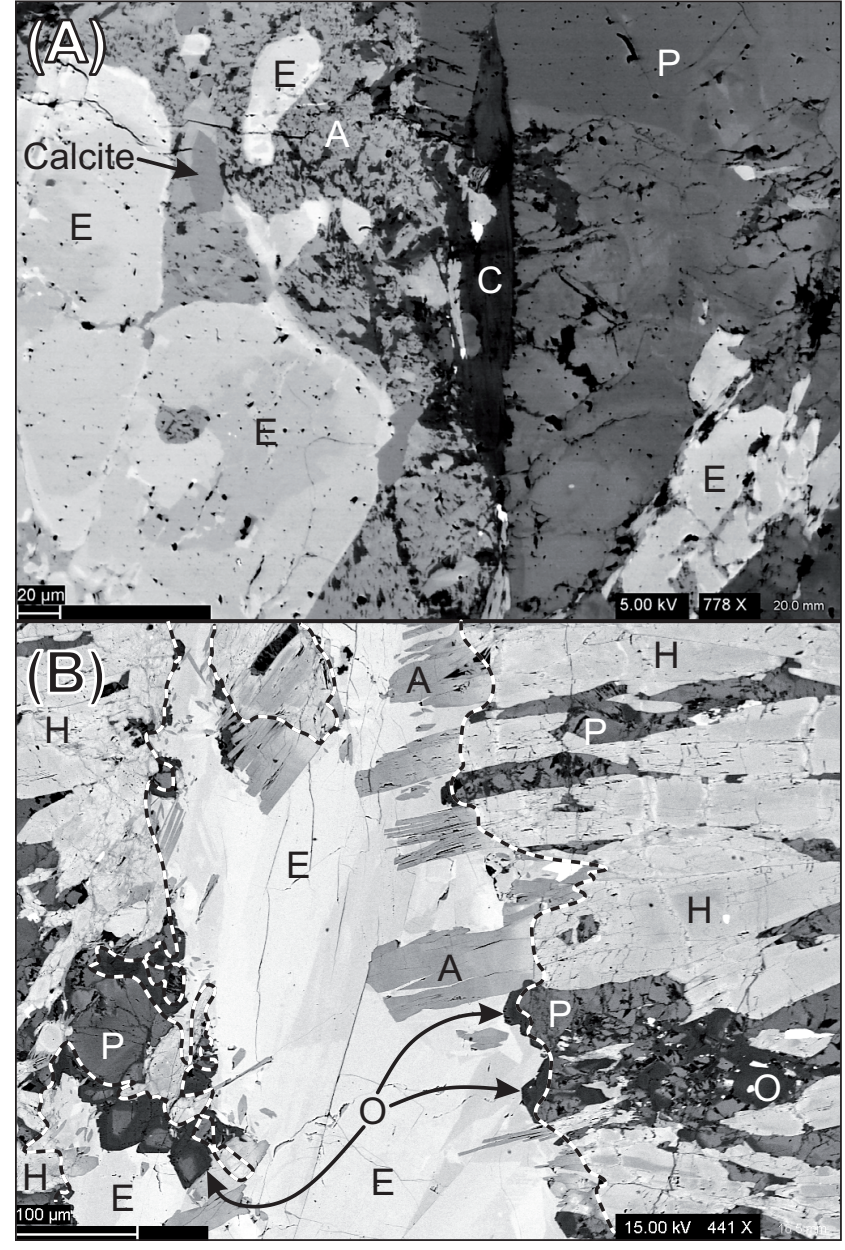

Figure 6. Backscattered electron images showing retrograde textures. (A) Sample 386: late retrograde minerals including actinolite, chlorite, and calcite. (B) Sample 386: vein, outlined with dashed lines, filled with actinolite, oligoclase, and epidote that overgrew, in optical continuity, their prograde counterparts on the vein walls. Abbreviations: A actinolite, $\mathrm{C}$ - chlorite, $\mathrm{E}$ - epidote, $\mathrm{H}$ - hornblende, $\mathrm{O}$ - oligoclase, $P$ - calcic plagioclase.

and lower metamorphic grades, with decreasing $\mathrm{Fe}^{3+}$ with increasing grade, commonly recorded by core to rim zoning in epidote (Grapes \& Hoskin, 2004). This is partly caused by prograde pumpellyite breakdown on entering the greenschist facies. At higher temperatures, during breakdown of epidote to produce plagioclase, it is the $\mathrm{Fe}^{3+}$-rich epidote that survives to highest grade. In these terms we can understand the four distinct epidote parts as (1) lower epidote amphibolite facies; (2) upper epidote amphibolite facies; (3) amphibolite facies leading to epidote breakdown; and (4) greenschist facies.

\section{Plagioclase}

Plagioclase tends to be strongly and irregularly zoned (Figs. 3D-F, 6A), with no consistent core to rim pattern. In the matrix, where the overwhelming bulk of plagioclase resides, seven samples have median plagioclase compositions of An62-69, spanning ranges of 31 An\% (sample 284) to $63 \mathrm{An} \%$ (sample 386). Sample 160 is 
notably more sodic, with a median matrix plagioclase of An44 and a range of $34 \mathrm{An} \%$. Sample 119 is considerably more calcic, with a median composition of An95 and a range of $6 \mathrm{An} \%$. Plagioclase inclusions in hornblende and diopside (samples 119, 161, 220, 379 only) have composition ranges similar to the associated matrix plagioclase.

The seemingly chaotic distribution of matrix plagioclase compositions probably reflects a combination of igneous relics and plagioclase that recrystallized and precipitated during all phases of metamorphism, quite different than the concentric zoning of epidote and amphibole. Sodic feldspar of An2-21 is only found in rare, late, thin brittle fractures and extensional spaces that are typically associated with fine-grained actinolite, spongy low-Fe epidote, chlorite, and nearly end-member calcite (Figs. 3E circled areas, 3F, 6A).

\section{Vein assemblage}

Fig. $6 \mathrm{~B}$ shows a vein in sample 386 that crosscuts the rock foliation and lineation. This vein is filled with epidote, actinolite, and plagioclase as optically continuous overgrowths on their prograde counterparts at the vein margins. The vein assemblage includes no diopside, chlorite, or calcite. The vein may be related to the small conjugate extensional faults visible in Fig. 2.

\section{Modeling strategies and results}

\section{Evaluation of model results}

Most minerals in these rocks have complex zoning, clearly indicating that only small parts of them were ever at equilibrium at any particular time. The zoning and wide composition ranges for most minerals in each sample made it initially difficult to decide which mineral parts represented which parts of the metamorphic history. To identify the peak prograde assemblage, for example, we interpreted optical and backscattered electron images, and mineral compositions, iteratively with thermodynamic modeling. To do this, a large series of exploratory isocompositional sections (i.e., 'pseudosections') were calculated with Perple_X (Connolly, 2009; Appendix 2), using different combinations of mineral parts (cores, mantles, rims, etc.) to calculate the system compositions for different model runs.

For our purposes the pertinent Perple_X model results included phase compositions and weight modes. All of the important phases, amphibole, diopside, plagioclase, and epidote, are solid solutions, so the accuracy of model predictions depends on the fundamental accuracy of the thermodynamic solution models. Because the solution models are continually being evaluated, and because some solution models are complex, with important uncertainties in the model constants, we generally elected to use several phase composition and modal characteristics to evaluate success or failure of model runs, rather than the minimum number of two to fix a point in P-T space. Fig. 7 illustrates how this was done.

Fig. 7 shows three schematic mineral phases in a ternary composition space, representing one thermodynamic exploratory model. The mineral compositions were selected for this model as having been hypothetically in equilibrium at some point in the metamorphic history (e.g., green hornblende rims, epidote mantles, and average matrix plagioclase; only three phases mentioned to better represent Fig. 7). The real mineral compositions (X symbols, Fig. 7) define the hypothetical equilibrium phase relations (solid triangle, Fig. 7A). The model system compositions (black dots) were calculated by combining the selected actual mineral compositions in some proportion (say 33:33:34\%). Note that these proportions are arbitrary. Changing them to other values has no substantive effect on model results, because a successful model will accurately reproduce both the phase compositions and phase proportions used to calculate the model system composition.

After each Perple_X model was run, the results in the entire P-T isocompositional section grid (101 x 101 grid, 10,201 points) were evaluated in two ways: (1) The model phase compositions (corners of the dashed triangles in Fig. 7) were compared to the actual compositions (X symbols). If the two matched within some range (e.g., $\pm 0.05 \mathrm{Na}$ per formula unit, or $\pm 5 \mathrm{Mg}$, solid hexagons), then the result for that phase, for that chemical component, was considered a good approximation of the actual phase composition. (2) The model phase proportions were compared to the phase proportions used to calculate the model system composition. If the two matched within some range (dashed hexagons, e.g., 33\% plagioclase $\pm 5 \%$ ), then that modal result was considered a good approximation of the original system phase proportions.

A schematic successful model is shown in Fig. 7A, where the model results (dashed triangle, representing phase relations at one particular $\mathrm{P}-\mathrm{T}$ grid point) match the actual phase proportions and compositions within chosen ranges. This result is interpreted to indicate the approximate $\mathrm{P}-\mathrm{T}$ condition where those mineral compositions were a stable metamorphic assemblage. For the same model run, at a different $\mathrm{P}-\mathrm{T}$ grid point, the results might be like that in Fig. $7 \mathrm{~B}$, where the model phases neither have compositions matching the actual minerals, nor phase abundances matching the proportions used to calculate the system composition. At a third P-T grid point the results might be like that in Fig. 7C, where model phase compositions do not match the actual mineral compositions, but model modes are in an acceptable range. At a fourth $\mathrm{P}-\mathrm{T}$ grid point (Fig. 7D), the model phases have acceptable compositions, and the modes might have been acceptable, but a fourth model phase (e.g., chlorite) takes up system components and displaces 


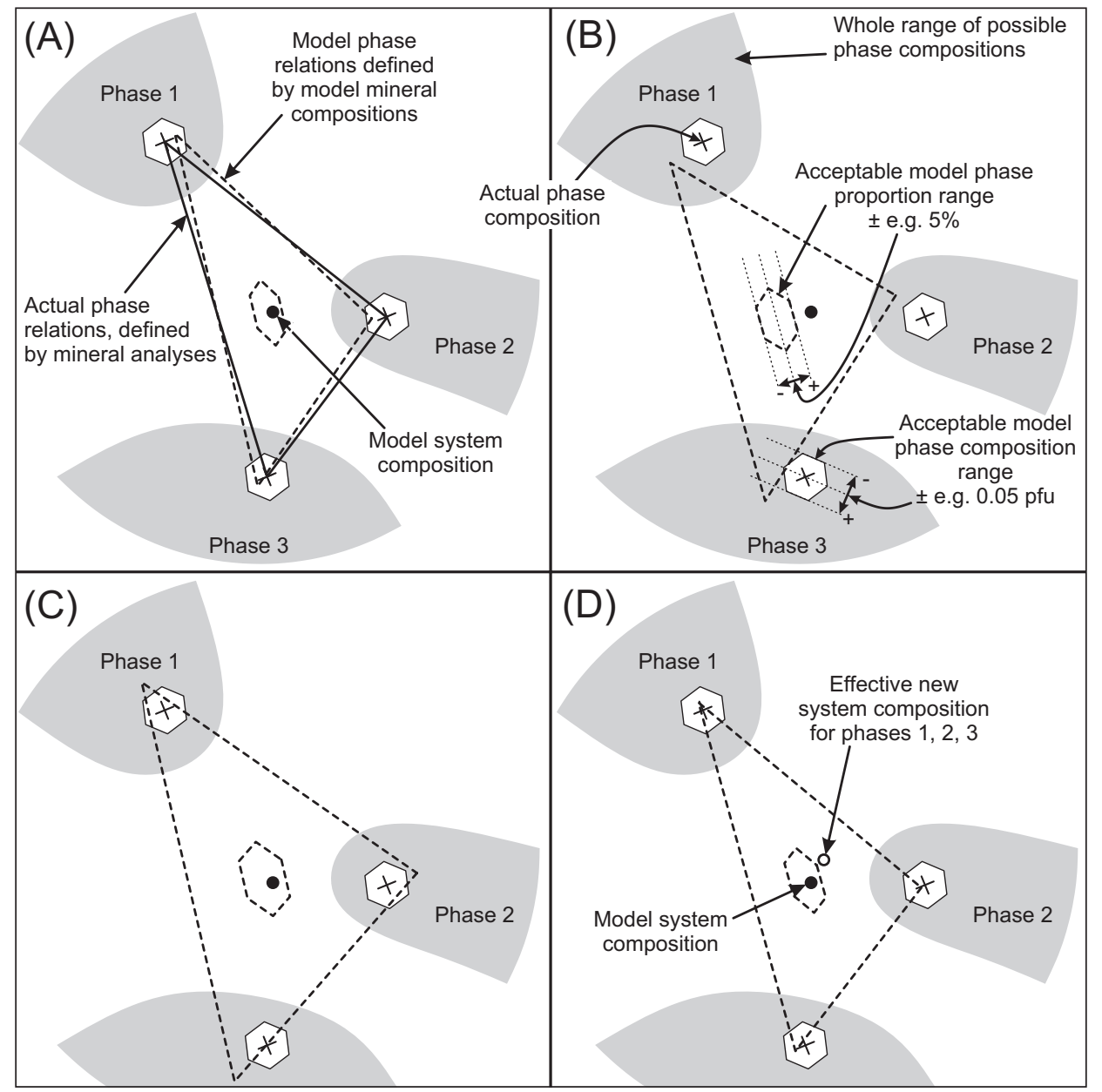

Figure 7. Conceptual framework for interpreting the success of Perple_X thermodynamic models on the basis of model phase compositions and proportions. Parts (A) to (D) all represent a single model run, but show results at four different $P-T$ conditions. (A) Actual phase relations are defined by mineral analyses (X symbols inside solid-line hexagons). At this $P-T$ condition the model is considered successful because model phase compositions (dashed-line triangle corners) plot within acceptable ranges (solid-line hexagons) of the actual mineral compositions, and the model system composition is within the small dashed hexagon of acceptable model phase proportions. (B) At a different P-T condition the model is considered unsuccessful, because model phase compositions lie outside the acceptable ranges, and the system composition lies outside of the range of acceptable model phase proportions. (C) At this P-T condition the model is unsuccessful because model phase compositions lie outside of the acceptable ranges, although the system composition is within the acceptable range of phase proportions. (D) Also unsuccessful, this model has phase compositions that are within acceptable ranges, but the presence of one or more model phases outside of the plane of this projection (e.g., chlorite), displaces the effective system composition for the three plotted phases (open circle) outside of the range of acceptable phase proportions.

the effective system composition available to phases 1,2 , and 3, causing this model to fail as well.

Note that model phase compositions and modes are partially redundant criteria, provided there are no extra model phases, like chlorite, beyond three (Fig. 7) or four (actual gabbros of this study). Though partially redundant, we chose to retain both compositional and modal criteria throughout, because using both made model results easier to interpret in terms of planning subsequent models.

A 'successful' model run must have some point or region in the P-T grid with results like that in Fig. 7A, or close to it. It was found that most model runs, using most combinations of mineral parts, yielded unsuccessful results at all P-T grid points (like Fig. 7B-D). Below we present only the successful model results (like Fig. 7A). We point out that our model evaluation method is really no different from those of other workers, except that we evaluated more compositional and modal factors at once, up to 11 , in recognition of uncertainties in the thermodynamic solution models.

\section{Peak prograde conditions}

For modeling purposes, the amphibole, plagioclase, diopside, and epidote parts chosen for each sample were combined in the proportions 30:30:30:10, respectively, to yield Perple_X model system compositions (Table 1, details in Appendix 3). For each sample we tested Al-rich hornblende rims and average diopside with all combinations of epidote mantles and $\mathrm{Fe}$ rich rims, and Na-rich, Ca-rich, and average matrix plagioclase. The following set of mineral compositions was the only one that yielded, in all samples, model phase compositions 
similar to the actual minerals, and model phase modal abundances similar to those used to calculate the system compositions (like Fig. 7A):

1. Average Al-rich hornblende rims, because of the almost universal texture of them covering actinolitic cores, implying prograde overgrowth.

2. Average matrix plagioclase, a surprise considering the wide ranges of available matrix compositions. This result implies that during deformation-induced recrystallization, the plagioclase component available for prograde reactions in the metamorphic fluid was an integrated mixture of all available matrix plagioclase compositions.

3. Average diopside. Diopside is nearly homogeneous for $\mathrm{Fe}$ and $\mathrm{Mg}$, except for rare, thin Fe-rich rims that were ignored. The low, somewhat variable $\mathrm{Na}$ and $\mathrm{Al}$ contents followed no clear pattern, perhaps like the zoning style in matrix plagioclase (Figs. 3D-F, 6A).

4. Average epidote mantles (Em in Fig. 3F), which make up most of the epidote mass in each sample, and which continuously cover early Fe-poor cores.

To illustrate the phase relations we use the $\mathrm{CaO}-\mathrm{AlO}_{1.5}-$ $\mathrm{Mg}(\mathrm{Fe}) \mathrm{O}-\mathrm{NaAlO}_{2}$ system, and project from diopside onto the $\mathrm{Mg}(\mathrm{Fe}) \mathrm{O}$-anorthite-albite plane (Fig. 8). The phase compositions listed above for peak prograde conditions for all samples are shown in Fig. 8A. Phase relations are reasonably consistent despite large differences in plagioclase and epidote compositions among the samples, uncertainties in amphibole $\mathrm{Fe}^{3+}$ estimates, and the finite number of analyses that contributed to averages used in the models.

Fig. 9A shows the phase stability fields generated by Perple_X for representative sample 122 (all samples treated identically). A calculated two-amphibole actinolite-hornblende field is shown in pink, above about 6 kbars. Because we saw no conclusive petrographic evidence for coexisting amphiboles, we ignored this field and calculated weighted averages for model amphibole compositions within it. Ignoring the two-amphibole field and minor model quartz above about 5.5 kbars, the model hornblende-diopside-epidote-plagioclase assemblage (the actual rock assemblage) occupies the blue field.

Fig. 9B-D illustrates model P-T fields in which model phase compositions match actual mineral compositions, and model mineral modes match the mineral modes used to calculate the model system composition, as discussed above. Fig. 9B shows fields where model weight proportions of hornblende, plagioclase, diopside, and epidote match the weight proportions (30:30:30:10, respectively) used to calculate the model system composition, $\pm 5 \%$. Fig. $9 \mathrm{C}$ shows the fields where model hornblende $\mathrm{Na}$ per formula unit $( \pm 0.05)$, hornblende $\mathrm{Mg}^{\prime}( \pm 5)$, and epidote $\mathrm{Fe}^{3+}$ per formula unit $( \pm 0.05)$ match the mineral compositions used to calculate the system composition. Fig. 9D shows where model fields match diopside $\mathrm{Mg}$ ' $( \pm 5)$, hornblende Al per formula unit ( \pm 0.1$)$, and plagioclase An\% ( \pm 5$)$. An additional criterion in Fig. 9D is the absence of model chlorite in the assemblage. The black regions in Fig. 9B-D show the $\mathrm{P}-\mathrm{T}$ conditions where all criteria in each figure overlap.

The Perple_X program used to calculate model mineral compositions and weight modes from model results (werami.exe) does so at discrete grid points, which we chose to be spaced $2^{\circ} \mathrm{C}$ and 40 bars apart in Fig. 9B-D. The points represent pixels, giving the fields in Fig. 9B-D stepped edges. In some instances the composition or weight mode gradient was very steep, with an extremely narrow matching criterion window (e.g., \pm An5 in plagioclase is $\leq 1$ pixel wide) that passed between, and so was missed by, the calculated points in adjacent pixels. In such cases the matching window was widened along the steep gradient until the algorithm recognized the criterion match in at least one pixel.

Fig. 9E shows all 11 matching criterion fields in Fig. 9B-D, superimposed in gray shades. All 11 fields overlap in one pixel near $530^{\circ} \mathrm{C}$ and $6 \mathrm{kbars}$, representing the best estimate for peak prograde metamorphic conditions for sample 122. For the other eight samples, 8 to 10 criteria

Table 1. System compositions used for Perple_X modeling, peak and early retrograde conditions (sample 386 vein), derived from mineral analyses.

\begin{tabular}{|l|c|c|c|c|c|c|c|c|c|c|}
\hline \multicolumn{1}{|c|}{ Sample } & 119 & 122 & 160 & 161 & 220 & 284 & 379 & 383 & 386 & 386 vein \\
\hline $\mathrm{SiO}_{2}$ & 48.78 & 50.67 & 52.05 & 50.88 & 50.52 & 51.04 & 49.95 & 50.41 & 51.67 & 52.94 \\
\hline $\mathrm{TiO}_{2}$ & 0.01 & 0.01 & 0.01 & 0.01 & 0.01 & 0.01 & 0.01 & 0.01 & 0.01 & 0.01 \\
\hline $\mathrm{Al}_{2} \mathrm{O}_{3}$ & 16.52 & 14.54 & 13.74 & 14.62 & 15.19 & 14.44 & 15.09 & 15.23 & 14.21 & 18.45 \\
\hline $\mathrm{Fe}_{2} \mathrm{O}_{3}$ & 1.58 & 1.80 & 1.80 & 1.89 & 1.75 & 1.64 & 2.37 & 1.82 & 1.82 & 1.98 \\
\hline $\mathrm{FeO}$ & 3.08 & 3.74 & 4.94 & 4.06 & 4.26 & 4.29 & 4.34 & 4.35 & 3.88 & 2.13 \\
\hline $\mathrm{MgO}$ & 9.94 & 9.77 & 8.78 & 9.36 & 9.04 & 9.32 & 8.96 & 8.92 & 9.46 & 6.96 \\
\hline $\mathrm{CaO}$ & 19.59 & 18.26 & 16.46 & 17.74 & 17.65 & 17.69 & 17.88 & 17.62 & 17.05 & 14.65 \\
\hline $\mathrm{Na}_{2} \mathrm{O}$ & 0.50 & 1.21 & 2.22 & 1.44 & 1.58 & 1.57 & 1.40 & 1.64 & 1.90 & 2.88 \\
\hline $\mathrm{Total}$ & $\mathbf{1 0 0 . 0 0}$ & $\mathbf{1 0 0 . 0 0}$ & $\mathbf{1 0 0 . 0 0}$ & $\mathbf{1 0 0 . 0 0}$ & $\mathbf{1 0 0 . 0 0}$ & $\mathbf{1 0 0 . 0 0}$ & $\mathbf{1 0 0 . 0 0}$ & $\mathbf{1 0 0 . 0 0}$ & $\mathbf{1 0 0 . 0 0}$ & $\mathbf{1 0 0 . 0 0}$ \\
\hline $\mathrm{Fe}^{3+} / \mathbf{F e}_{\text {total }}$ & $\mathbf{0 . 2 9 6}$ & $\mathbf{0 . 3 1 3}$ & $\mathbf{0 . 2 1 7}$ & $\mathbf{0 . 2 9 2}$ & $\mathbf{0 . 2 6 2}$ & $\mathbf{0 . 2 2 1}$ & $\mathbf{0 . 3 5 7}$ & $\mathbf{0 . 2 7 2}$ & $\mathbf{0 . 3 0 3}$ & $\mathbf{0 . 2 5 4}$ \\
\hline
\end{tabular}


overlapped in at least one pixel in a similar way, all close to $530^{\circ} \mathrm{C}$ and $6 \mathrm{kbars}$. Fields that missed the dominant point of overlap did so typically by $<25^{\circ} \mathrm{C}$ and $<0.5$ kbars. Fig. 9F illustrates the result of superimposing all eleven criteria matching fields, for all nine samples, (total 99 criteria), where 64 of the fields (65\%) overlap at a single pixel near $530^{\circ} \mathrm{C}$ and $6 \mathrm{kbars}$. The most common criterion to fail was $\mathrm{Fe}^{3+}$ in epidote, which tended to be lower in model epidote compared to average epidote mantles in each sample.

Some model criterion fields that match the actual mineral compositions or modal proportions cover broad P-T areas, such as Mg' in model hornblende and diopside in Fig. 9C, D. In addition, some of the fields and field edges are nearly parallel and coincident, commonly occurring close to the epidote-out line (Fig. 9A). Two consistently narrow matching criteria that intersect at a large angle, plagioclase $\mathrm{An} \%$ and $\mathrm{Al}$ in hornblende, were selected to summarize the full set of 11 criteria. Fig. 10 shows matching $\mathrm{An} \%$ in plagioclase and $\mathrm{Al}$ in hornblende for eight samples, superimposed (119 is omitted, discussed below). These two criteria overlap in a small area near $530^{\circ} \mathrm{C}$ and $6 \mathrm{kbars}$. Also shown are the centers of the overlap areas for each sample, and uncertainty ellipses for the overlap regions are shown in the inset.

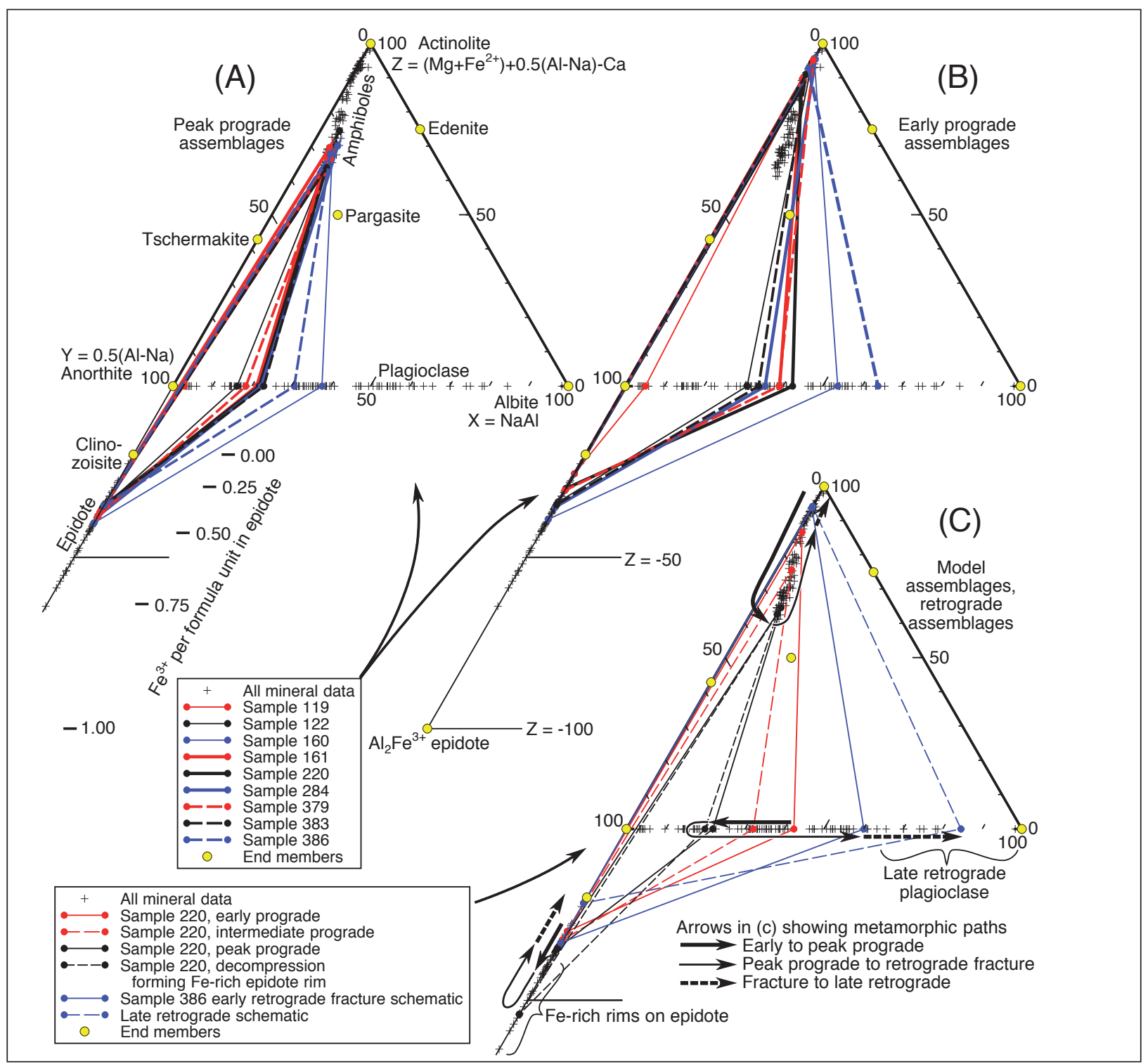

Figure 8. Chemographic diagrams showing mineral analyses and interpreted phase relations for all nine samples. This is in the quaternary $\mathrm{Mg}(\mathrm{Fe}) \mathrm{O}-$ $\mathrm{AlO}_{15}-\mathrm{NaAlO}_{2}-\mathrm{CaO}$ system, projected from diopside onto the $\mathrm{Mg}(\mathrm{Fe}) \mathrm{O}$-albite-anorthite plane. Projection from diopside was chosen because diopside is ubiquitous in prograde assemblages, and has a small composition range (Fig. 5C). (A) Three-phase fields for all nine samples, showing peak prograde assemblages. (B) Three-phase fields for parts of minerals interpreted to best represent early prograde assemblages in all nine samples (low-Fe epidote cores or inclusions are not available for sample 386). (C) Model phase relations for the prograde, decompression, and cooling metamorphic paths using sample 220 as an example, with the progression of model phase compositions highlighted with arrows. Also shown is the early retrograde vein assemblage in sample 386 (schematic; see Fig. 6B), and the late retrograde mineral compositions found in fractures (schematic, using one late retrograde plagioclase analysis from sample 220 and estimated spongy epidote and fine-grained actinolite compositions; Figs. 3F, 6A). 
For sample 119, model Al in amphibole and plagioclase An\% match the actual mineral compositions in the $\mathrm{P}-\mathrm{T}$ range of Fig. 10, but not in an overlapping region. This contrasts with two nearby samples in the same unit (122 is from a few meters away, 220 from about $2 \mathrm{~km}$ to the west). Sample 119 has anomalously calcic matrix plagioclase (average An95, range An90-96), particularly compared to its prograde hornblende rim composition which is in the middle of the range for all other samples (average green hornblende $\mathrm{Ca} /(\mathrm{Ca}+\mathrm{Na})$ in the other samples ranges from 0.87 to 0.91 , and is 0.89 in sample 119). The presence of hornblende rims in sample 119 that are similar in composition to all other samples, in the presence of anomalously calcic plagioclase, may be

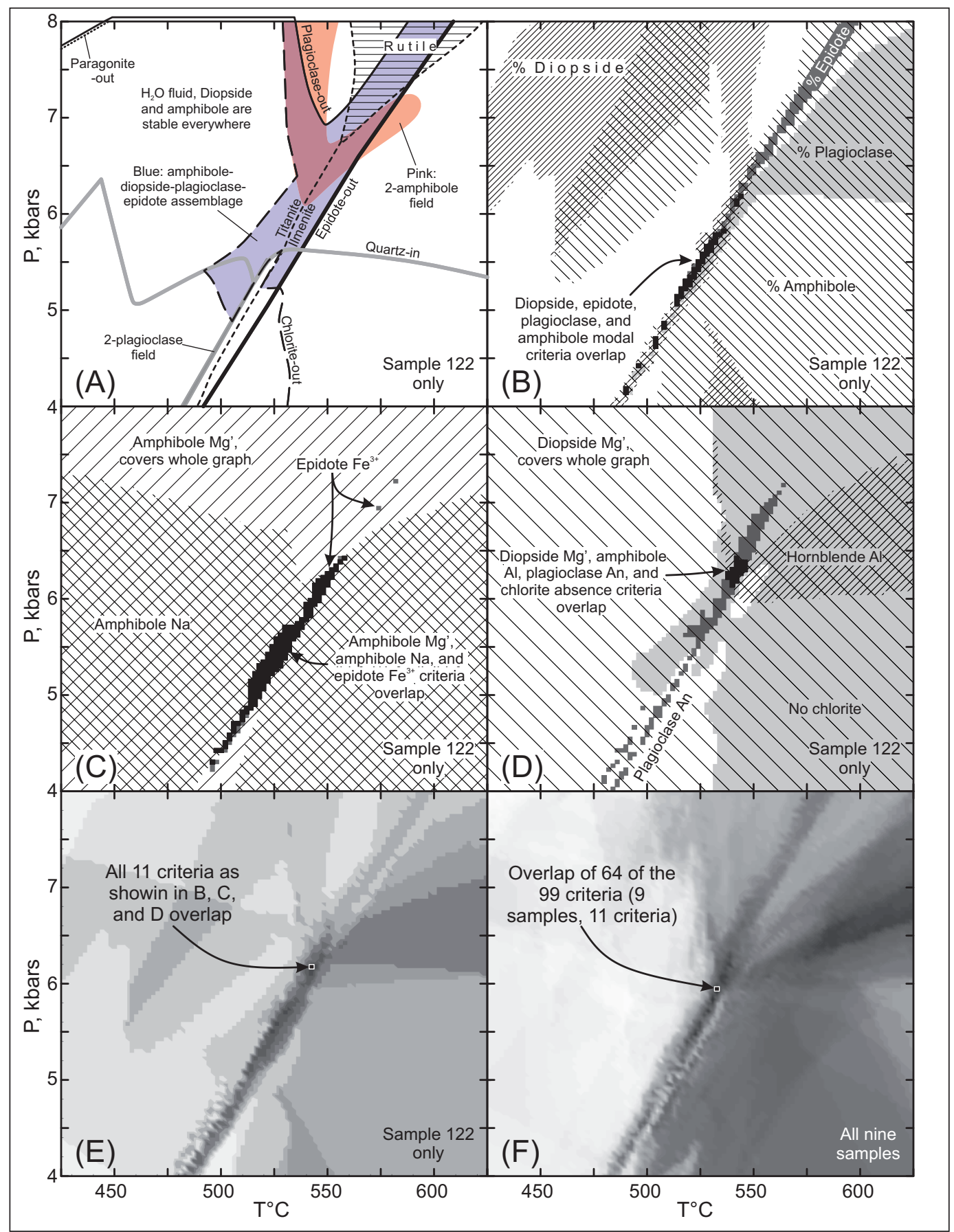

Figure 9. Perple_X peak prograde modeling results for representative sample 122 (A-E), and all nine samples (F). (A) Model phase stability fields, highlighting the rutile stability field (horizontal lines), a two-amphibole actinolite-hornblende field (pink), and the region containing the peak prograde assemblage (blue, ignoring minor quartz and the two amphibole field). (B) Fields where model hornblende, diopside, plagioclase, and epidote mineral modes match the modes used to calculate the peak prograde model composition. (C) Fields where three model mineral compositions match the actual mineral compositions. (D) Same as (C), but for three different minerals, plus the field where model chlorite is absent. (E) All fields from (B), (C), and (D) combined. The darkest regions have the most overlapping fields, with all 11 fields overlapping in one pixel. (F) Same as (E), but showing all nine samples superimposed. The pixels in $B-F$ are $2^{\circ} \mathrm{C}$ by 0.04 kbars in size, where model mineral modes and compositions were calculated on a uniform grid. 


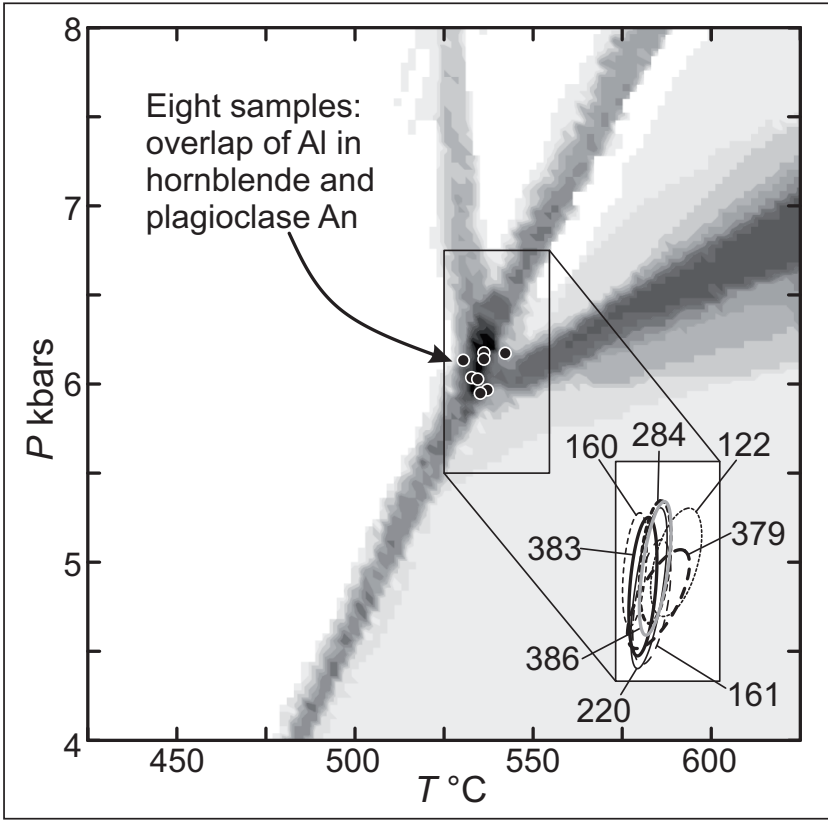

Figure 10. Estimated peak prograde metamorphic conditions for eight samples (sample 119 omitted, see text), where model plagioclase and Al in hornblende compositions match the actual mineral compositions used to calculate the model systems. Black dots are the centers of pseudouncertainty ellipses shown in the inset. The ellipses were calculated for the pixels where model amphibole Al and plagioclase An compositions matched those of the actual minerals. These had a flat point distribution rather than Gaussian, so the ellipses were sized to encompass 95\% of matching pixels for the eight plotted samples.

related to the difference between the sample 119 model and the rest in Fig. 10.

\section{Early prograde conditions}

Perple_X models for peak prograde conditions all indicate that earlier, lower temperature assemblages should have had actinolitic amphibole, low-Fe epidote, An-poor plagioclase, and diopside. Relics from those early conditions are presumably actinolite cores inside hornblende, Fe-poor epidote cores, and inclusions

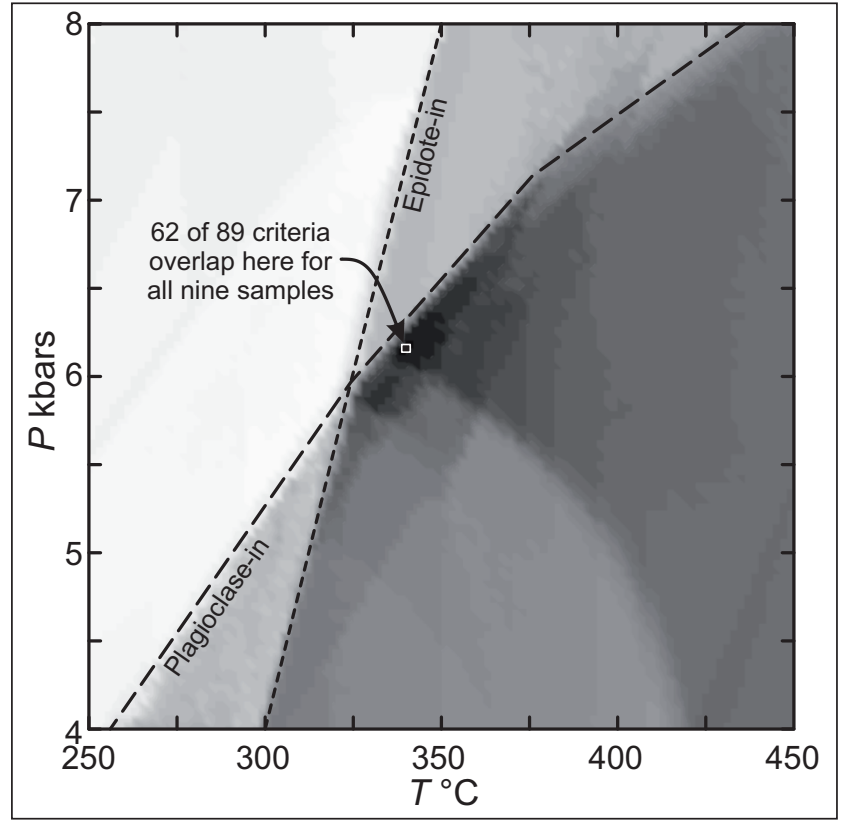

Figure 11. Estimate of early prograde metamorphic conditions, indicated by the overlap of model mineral mode and compositional criteria (see text) with the minerals used to calculate the model system compositions. Dashed lines show the approximate locations, based on all nine samples, of the fields to the right of which plagioclase and epidote are present. To the left of those lines the epidote and plagioclase chemical components are redistributed into other model phases, including chlorite, lawsonite, pumpellyite, and paragonite.

of early metamorphic minerals inside actinolite and diopside (Fig. 3A-C; samples 119, 161, 220, 284, 386, other samples had no analyzable silicate inclusions). It seems likely that An-poor plagioclase in the matrix is also relict from early prograde conditions, but chaotic zoning made it difficult to select clear examples.

Our most successful strategy for modeling early prograde conditions was to use modified whole-rock compositions (Table 2). The modifications were necessary to fit the thermodynamic solution models, and involved

\begin{tabular}{|c|c|c|c|c|c|c|c|c|c|}
\hline Sample & 119 & 122 & 160 & 161 & 220 & 284 & 379 & 383 & 386 \\
\hline $\mathrm{SiO}_{2}$ & 49.83 & 50.02 & 50.99 & 51.00 & 51.00 & 50.59 & 50.69 & 49.95 & 50.42 \\
\hline $\mathrm{TiO}_{2}$ & 0.01 & 0.01 & 0.01 & 0.01 & 0.01 & 0.01 & 0.01 & 0.01 & 0.01 \\
\hline $\mathrm{Al}_{2} \mathrm{O}_{3}$ & 14.62 & 15.81 & 15.65 & 15.47 & 17.22 & 16.84 & 16.35 & 15.42 & 15.95 \\
\hline $\mathrm{Fe}_{2} \mathrm{O}_{3}$ & 0.62 & 0.65 & 0.85 & 0.75 & 0.62 & 0.75 & 0.73 & 0.90 & 0.71 \\
\hline $\mathrm{FeO}$ & 5.06 & 5.27 & 6.87 & 6.08 & 5.01 & 6.11 & 5.88 & 7.26 & 5.78 \\
\hline $\mathrm{MgO}$ & 13.09 & 11.43 & 9.70 & 10.80 & 9.24 & 9.70 & 10.28 & 11.33 & 11.00 \\
\hline $\mathrm{CaO}$ & 15.92 & 15.62 & 13.87 & 14.18 & 14.64 & 13.73 & 14.00 & 13.13 & 14.35 \\
\hline $\mathrm{Na}_{2} \mathrm{O}$ & 0.85 & 1.19 & 2.06 & 1.71 & 2.26 & 2.27 & 2.06 & 2.00 & 1.78 \\
\hline Total & 100.00 & 100.00 & 100.00 & 100.00 & 100.00 & 100.00 & 100.00 & 100.00 & 100.00 \\
\hline
\end{tabular}


removing chemical elements from the bulk compositions as idealized metamorphic phases or solid solution components (e.g., Ti removed as titanite; see Appendix 3). Model results for each sample were compared to the following 10 mode and composition criteria: $>1 \%$ each of amphibole, diopside, plagioclase, and epidote; $\mathrm{Mg}$, $\mathrm{Al}$, and $\mathrm{Na}$ values for actinolite having the lowest $\mathrm{Al}$ content; $\mathrm{Mg}$ ' for diopside; the lowest An\% for plagioclase inclusions in diopside or actinolite (or matrix plagioclase if inclusions were absent, samples $122,160,379,383$ ), and low-Fe epidote cores or inclusions having the lowest Fe content (neither were available in sample 386, so the total number of criteria in Fig. 11 is 89 instead of 90 ( 9 samples, 10 criteria). Chlorite was common in lowtemperature model assemblages but none was found as inclusions. Because absence of chlorite inclusions does not prove it was not once present, the presence or absence of model chlorite was not used as a matching criterion.

We recognize that the mineral compositions chosen to compare with the models are somewhat ad hoc, but for early prograde metamorphic conditions they are probably the best constraints available. The phase relations implied by the selected mineral compositions are shown for all samples in Fig. 8B. Fig. 11 shows the results from all nine samples, with gray fields overlapped as in Fig. 9F. 62 of 89 criteria $(70 \%)$ from all nine samples overlap at one pixel near $350^{\circ} \mathrm{C}$ and $6 \mathrm{kbars}$, a proportion similar to that for peak prograde conditions in Fig. 9F. Most criterion fields that miss that point do so by generally $<0.5$ kbars and $<25^{\circ} \mathrm{C}$. We take this point as a crude measure of early prograde conditions.

\section{Early retrograde conditions}

Evidence of retrograde metamorphism is difficult to find in most samples using optical microscopy. Sample 386 is unique in this set, having a relatively coarsegrained, undeformed vein that crosscuts the older foliation and lineation at a high angle (Fig. 6B). This vein may be related to late deformation that produced the small conjugate shear zones seen in Fig. 2. Vein filling consists of optically continuous overgrowths on prograde amphibole, plagioclase, and epidote on vein walls. The compositions of the vein overgrowths vary somewhat. Plagioclase (An25-34), and actinolite (0.11-0.26 Al per formula unit), become progressively lower in $\mathrm{An} \%$ and $\mathrm{Al}$, respectively, from the vein margin inward. Unfortunately, different epidote compositions $\left(0.23-0.42 \mathrm{Fe}^{3+}\right.$ per formula unit) appeared to be randomly in contact with different actinolite and plagioclase compositions. It was therefore not possible to match particular vein filling stages among the three facture filling phases. We therefore averaged mineral fill compositions and combined them in the weight proportions 34:33:33, for epidote, actinolite, and plagioclase, respectively, for the model system (Table 1). These phase compositions are shown schematically in Fig. 8C.
The model was compared to the following eight matching criteria for the sample 386 vein assemblage (Fig. 12): actinolite, plagioclase, and epidote modal abundances the same as that used to calculate the model system composition $( \pm 5 \%)$, absence of diopside and chlorite, $\mathrm{Al}$ per formula unit in actinolite ( \pm 0.05$), \mathrm{An} \%$ of plagioclase ( \pm 5 ), and $\mathrm{Fe}^{3+}$ per formula unit in epidote ( \pm 0.05$)$. All eight criteria match the model in a small region near $440^{\circ} \mathrm{C}$ and $3 \mathrm{kbars}$ (Fig. 12).

\section{Late retrograde conditions}

All nine samples contain small, irregular domains that are dominated by chlorite, fine-grained actinolite (crystals $\sim 10 \mu \mathrm{m}$ long), sodic plagioclase (An2-21), spongy low-Fe epidote, and nearly pure calcite (Fig. 3C, E, circled regions, and F, spongy epidote Es; Fig. 6A). These domains appear to occur along discontinuous brittle fractures. Because the phases in these domains were not found together to form a complete assemblage, and because good analyses could not be obtained on some phases because of minute grain sizes (actinolite) or apparently porous grains (spongy epidote), we were unable to justify thermodynamic modeling. Phase assemblage results from the other models, and the irregular, fine-grained nature of minerals in these domains, suggest that they formed at lower temperature, and possibly lower pressure, than the coarse, early retrograde vein assemblage (Fig. 6B). Fig. 8C schematically shows phase relations in the late retrograde domains, using from them one sodic plagioclase composition, and the approximate compositions of fine-grained actinolite and spongy epidote.

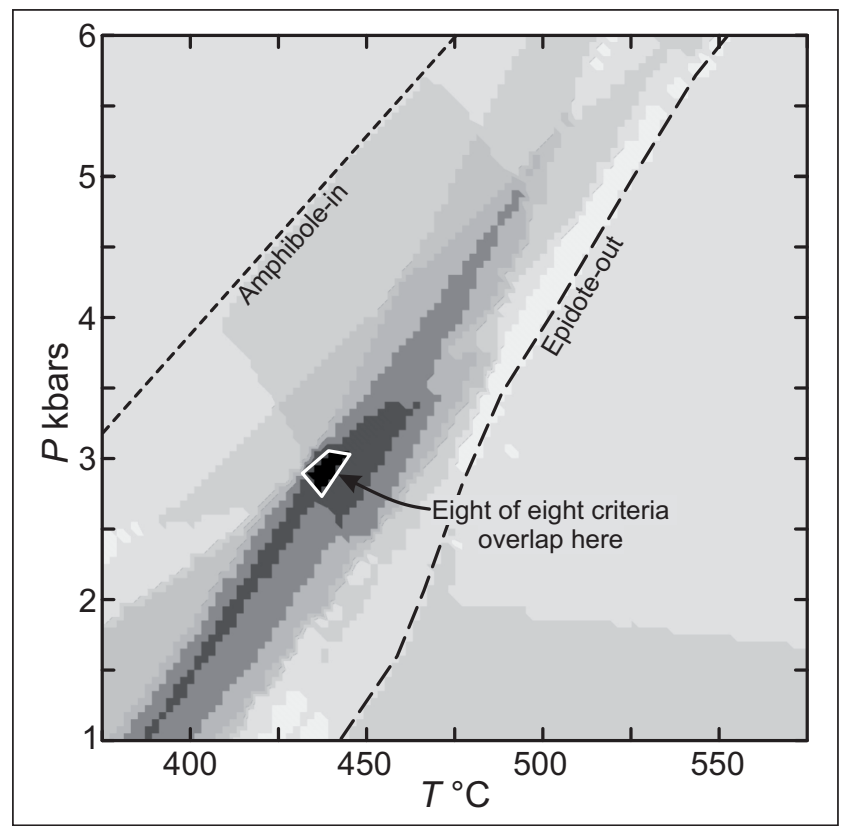

Figure 12. Estimate for early retrograde metamorphic conditions, based on the vein assemblage in sample 386 (Fig. 6B), as indicated by the overlap of actual mineral mode and compositional criteria with the model system (see text). 


\section{Model precision and accuracy}

Model precision, as indicated by estimated peak prograde conditions for different rocks in Fig. 10, seems to be approximately $\pm 15^{\circ} \mathrm{C}$ and \pm 0.5 kbars. Accuracy is more difficult to assess, because it is affected by analytical accuracy, the finite number and selection of mineral compositions used to represent particular parts of the metamorphic history (used to calculate model system compositions), and accuracy of the thermodynamic solution models. We believe that the largest uncertainties are associated with the latter two sources. We suggest model accuracy, at least for peak prograde conditions, of $\pm 50^{\circ} \mathrm{C}$ and \pm 1 kbar.

\section{Discussion}

\section{Regional metamorphic timing}

Presented above is evidence from metamorphosed Støren Group gabbros for four points on a metamorphic P-T path: early prograde $\left(\sim 350^{\circ} \mathrm{C}, \sim 6 \mathrm{kbars}\right)$, peak prograde $\left(\sim 530^{\circ} \mathrm{C}, \sim 6 \mathrm{kbars}\right)$, early retrograde $\left(\sim 440^{\circ} \mathrm{C}, \sim 3\right.$ kbars $)$, and late retrograde $\left(<440^{\circ} \mathrm{C}\right.$ inferred $)$. In reviewing these results one needs to consider the possibility that the Støren Group of the Upper Allochthon may have experienced as many as four episodes of metamorphism in different paleogeographic settings (Roberts, 2003): two Ordovician, Silurian and earliest Devonian, and Early Devonian.

1. A 500-480 Ma ophiolite and oceanic arc, corresponding to the Støren Group of the future Upper Allochthon, was obducted at $\sim 480-475 \mathrm{Ma}$ onto the Gula Complex, within or at the margin of Iapetus (see above, and the discussion in Hollocher et al., 2012). At present, we suggest that the Løkken and related Cambrian-earliest Ordovician ophiolites were emplaced onto the Laurentian margin, as demonstrated by overlying fossil strata, even though the substrate below the obduction surface is not presently exposed.

2. Mid to Late Ordovician deformation associated with the Taconian arc-continent collision on the Laurentian margin. This episode is apparently recorded mainly in the Uppermost Allochthon, and the highest parts of the Upper Allochthon exposed on Smøla (Fig. 1 , distant from rocks of this study).

3. Silurian and earliest Devonian Scandian collision between Laurentia and Baltica (Fig. 13A), with subduction of parts of the Baltican margin, eclogite formation (Krogh et al., 2011), and nappe emplacement. Evidence in the Upper Allochthon for this in the area of Fig. 1 includes deformational fabric development in the Lower and Upper Hovin groups and related units, and in most of the 439-431 Ma plutons that cut the Upper Allochthon east and south of Trondheim (Pannemans \& Roberts, 2000; Nilsen et al., 2003, 2007; Bingen \& Solli, 2009).

4. Late Early Devonian movement along the Agdenes detachment fault (Robinson et al., 2014; Fig. 13B, C), during which deep, hot rocks were emplaced against the cooler Upper Allochthon. This episode continued into the period of orogen-parallel extension superimposed on that detachment (Terry \& Robinson, 2003; Robinson et al., 2004, 2014; Osmundsen et al., 2006). The last part of this episode is confidently dated in the northern Western Gneiss Region at $395 \mathrm{Ma}$, or late Emsian, in the Early Devonian (Tucker et al., 2004; Krogh et al., 2011).

The Ordovician settings in particular are controversial because the Ordovician history of rocks in the Upper Allochthon is under continual revision. Present indications are based primarily on affinities of rare fossils in the Lower Hovin Group, which unconformably overlies Støren Group ophiolites. For the western part of the allochthon, including the Løkken and related ophiolites and their Lower to Middle Ordovician, post-obduction cover, these suggest a peri-Laurentian equatorial setting. This is also indicated for the Early Ordovician strata of Smøla, both based on a classic Toquima-Table Head fauna (Pedersen et al., 1992). For the southeastern part of the allochthon, the Early Ordovician Celtic fauna at Otta (Harper et al., 2008), as well as earliest Ordovician black shale chemistry (summarized in Hollocher et al., 2012) in the Meråker Nappe, immediately east of the Gula Nappe, suggest a high-latitude peri-Gondwanan setting.

\section{Upper Allochthon metamorphism, other workers}

Eide \& Lardeaux (2002) described a relict glaucophanebearing assemblage near the base of the western Bymarka ophiolite, and interpreted its origin to the obduction event (metamorphic episode 1). Roberts et al. (2002) and Roberts (2003) concurred with that assessment. The glaucophane-bearing assemblage (Eide \& Lardeaux estimated $400-500^{\circ} \mathrm{C}, 8-10 \mathrm{kbars}$ ) was strongly affected by a later epidote amphibolite facies overprint $\left(530-620^{\circ} \mathrm{C}\right.$, 5-6 kbars), similar to our estimates for peak prograde metamorphic conditions in gabbros. The Støren Group is unconformably overlain by the Lower Hovin Group and related rocks (Roberts et al., 1984, 2002), as described above. The Støren Group, where in contact with the Lower Hovin Group, such as the Løkken and Størås areas, generally records greenschist facies assemblages (e.g., Grenne \& Lagerblad, 1985; Roberts, 1987; Grenne, 1989; Hollocher et al., 2012). Although this widespread greenschist facies metamorphism appears to be unambiguously from metamorphic episode 1, the timing of the epidote amphibolite facies overprint on the glaucophanebearing assemblage is not so clear.

In the Einunnfjellet-Savalen area (Fig. 1) the Middle Allochthon is exposed in a window through the Upper Allochthon (McClellan, 2004). Garnet-biotite thermometry indicated smoothly varying estimated temperatures from $\sim 565^{\circ} \mathrm{C}$ in the structurally deeper Middle Allochthon to $\sim 495^{\circ} \mathrm{C}$ in the Upper Allochthon surrounding 


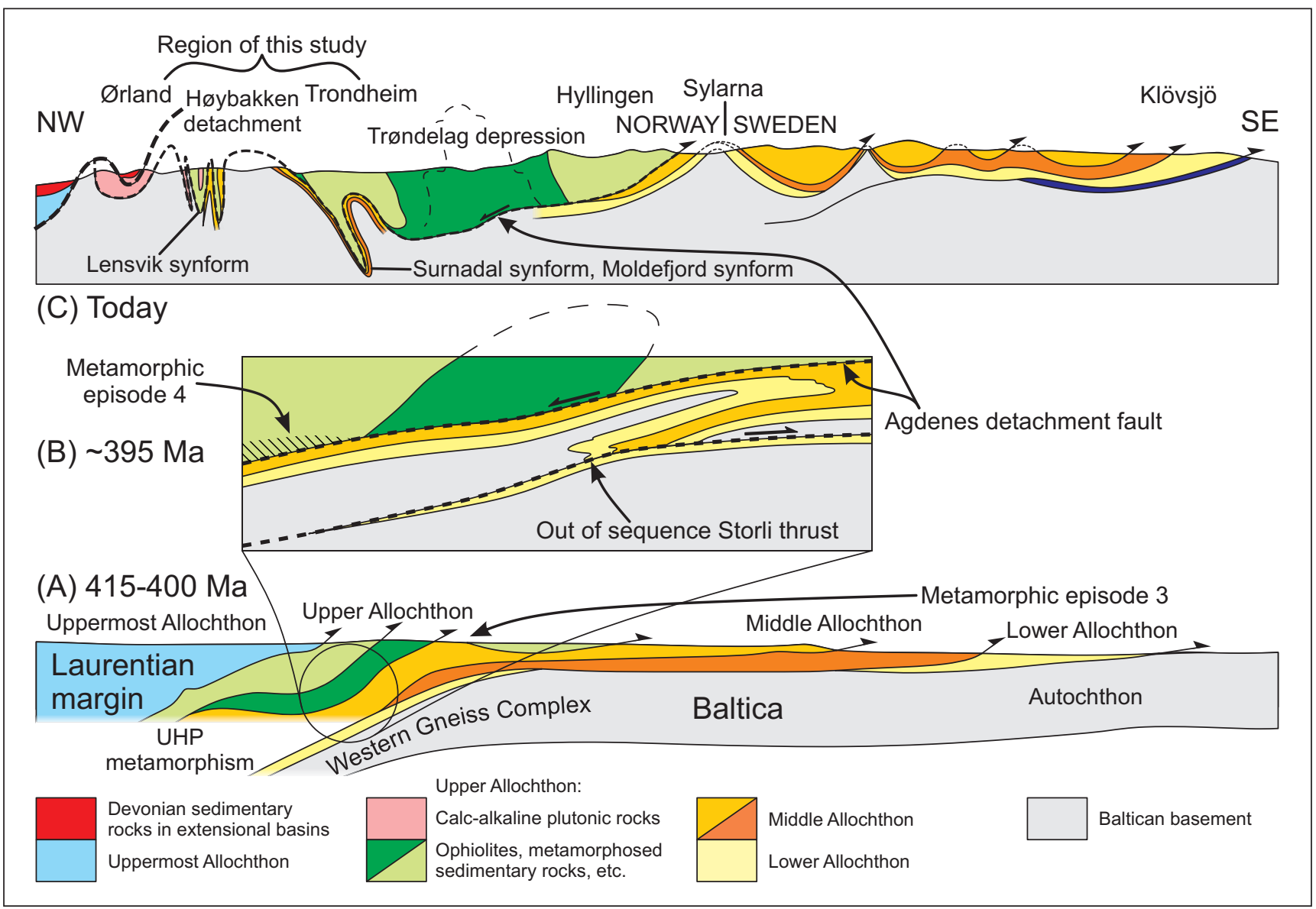

Figure 13. Schematic tectonic and geologic cross sections showing development of the central Scandinavian Caledonides, and metamorphic episodes 3 and 4 (see text). (A) and (C) are oriented approximately northwest-southeast with respect to the current landscape, and (B) is oriented approximately east-west. Unit colors are the same as in Fig. 1. (A) is after Hacker \& Gans (2005), (B) is after Robinson et al. (2014), (C), left side, is after Hollocher et al. (2012), and (C), right side, is after Gee et al. (1985).

the window. Pressures were crudely estimated to be $\sim 6$ kbars. This metamorphism was interpreted to be Scandian, corresponding to metamorphic episodes 3 or 4 , above.

Hacker \& Gans (2005), working in the Upper Allochthon of the central Trøndelag area (Fig. 1), estimated metamorphic conditions to have been $575-660^{\circ} \mathrm{C}$ and $8-10$ kbars. These P-T estimates are higher than the two studies mentioned above, and our work. We think the most likely reason for the difference is that the Hacker \& Gans P-T estimates record an earlier metamorphic episode, as indicated by associated ${ }^{40} \mathrm{Ar}-{ }^{39} \mathrm{Ar}$ dates on hornblende, muscovite, and biotite that span 402-436 Ma (their fig. 7). This is considerably older than the time of tectonic unroofing and metamorphism inferred for rocks we describe ( $395 \mathrm{Ma})$, in a region farther west (Fig. 1). Note that the Seve Nappe, included as part of the Upper Allochthon by Hacker \& Gans (2005), is now assigned to the Middle Allochthon (Andrèasson \& Gee, 2008). Those parts were ignored for our discussion.

${ }^{40} \mathrm{Ar}-{ }^{39} \mathrm{Ar}$ ages in the Upper Allochthon of the central Scandinavian Caledonides generally record Silurian and Early Devonian (Scandian) cooling ages in hornblende and micas over broad areas, in most cases probably representing cooling from metamorphic episodes 3 and 4 (Gäddede area, Dallmeyer \& Gee, 1988; northern Trøndelag area, Dallmeyer, 1990; central Trøndelag area, Hacker \& Gans, 2005). Evidence for Late Cambrian and early Ordovician ${ }^{40} \mathrm{Ar}-{ }^{39} \mathrm{Ar}$ plateau ages are found in the Tännforsen area, indicating a region where amphibole from metamorphic episode 1 survived Scandian resetting (Dallmeyer et al., 1985).

Working in Lower Allochthon Mesoproterozoic rocks in the northern Western Gneiss Region, Tucker et al. (2004) found that titanite $\mathrm{U}-\mathrm{Pb}$ ages were disturbed at $~ 395$ Ma throughout a large area. The amount of disturbance generally increased from $<10 \%$ along the western margin of the Trøndelag depression, to $100 \%$ near the coast to the northwest. There was apparently no titanite disturbance in the Upper Allochthon, above the Agdenes detachment fault, even along the coast (Tucker et al., 2004; Robinson et al., 2008, 2014). Disturbance was apparently related to deformation-induced titanite recrystallization (Spencer et al., 2012), when the deeply buried Lower and Middle allochthons were exhumed along the Agdenes detachment (Robinson et al., 2008, 2014). Tectonic exhumation accompanied Devonian red sandstone and conglomerate 
deposition in extensional basins above the Høybakken detachment fault and other extensional detachment faults elsewhere in coastal Norway (Figs. 1, 13; e.g., Andersen, 1998; Vetti \& Fossen, 2012).

The discussion above suggests that the Støren Group in the study area underwent extensive, though variable metamorphism in the Late Cambrian and early Ordovician (metamorphic episode 1), and underwent regional overprinting during the Scandian (episodes 3 or 4, Fig. 13), resetting most ${ }^{40} \mathrm{Ar}-{ }^{39} \mathrm{Ar}$ ages but not titanite. It seems highly likely that the rocks on which we report had been metamorphosed to greenschist facies during metamorphic episode 1. This assemblage was then transformed during higher grade metamorphism and severe deformation associated with metamorphic episode 4 .

\section{Structural interpretation and $P-T$ path}

An insight into the structural environment of these gabbros during metamorphism is provided by understanding the nature of the Agdenes detachment fault, as exposed in a continuous section on the west coast of Bolsøy (Fig. 1, samples 160 and 161), and other places in the Moldefjord and Surnadal synforms. In those areas the Agdenes detachment is the contact between the base of the Upper Allochthon Støren Group and the underlying Middle Allochthon Blåhø Nappe. Earlier, Krill (1985) recognized this contact as a significant metamorphic discontinuity, juxtaposing lower-grade rocks above against higher-grade rocks below. Robinson (1995) recognized the same thing in detailed descriptions of metamorphic assemblages on Bolsøy.

In the lowest part of the Blåhø section on Bolsøy, garnet-biotite schists show sinistral tails on porphyroclastic garnets, suggesting limited mineral growth during late deformation of minerals formed during earlier highgrade metamorphism. Higher in the section and closer to the detachment, by contrast, the garnets are euhedral porphyroblasts. These indicate significant late mineral growth which, we suggest, was enhanced by fluids released from the progressively warming and dehydrating base of the Støren Nappe as it slid into contact with the relatively hot, but progressively cooling, lower nappe along the Agdenes detachment fault. Locally in the Blåhø Nappe this produced porphyroblastic assemblages with newly grown garnet, staurolite and even kyanite, in rocks barely $1 \mathrm{~m}$ from the tectonic contact (Robinson, 1995).

At the same time, rocks in the Støren Nappe of the Upper Allochthon, above the Agdenes detachment, were undergoing prograde metamorphism (Fig. 13B), most likely from earlier greenschist facies assemblages, along the early to peak prograde path (Fig. 14). Rare aluminous layers in the Støren Group developed fine spongy garnet porphyroblasts and even staurolite. Such heating of a cool upper plate, transported along a detachment fault into contact with a hot, deeply exhumed lower plate, has

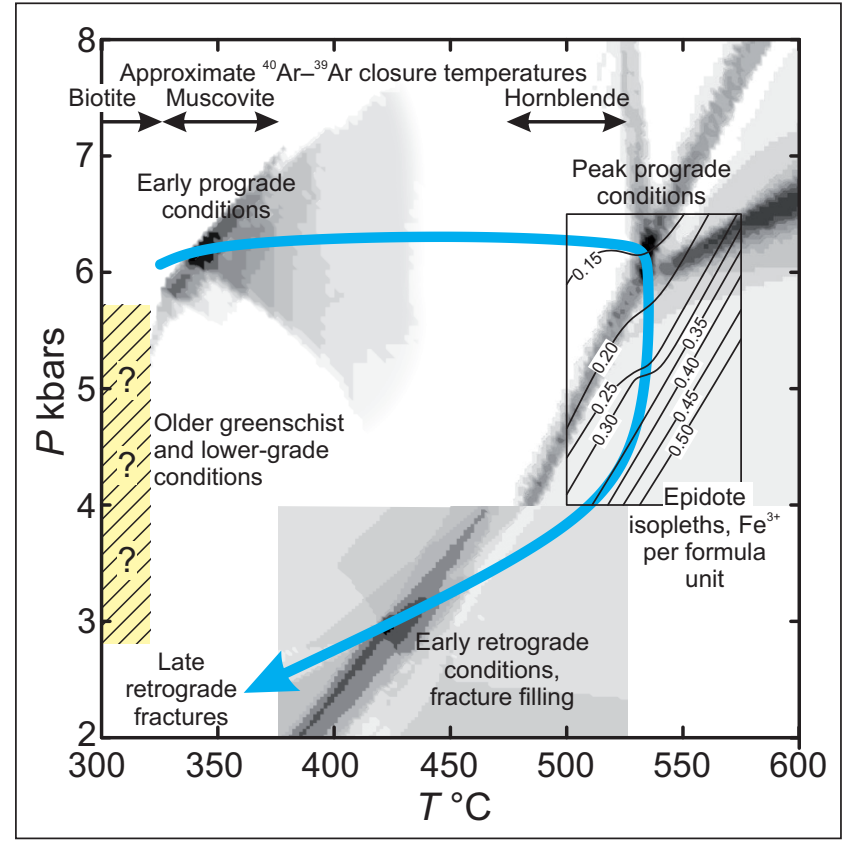

Figure 14. Hypothetical pressure-temperature path for rocks of this study, based on Figs. 10, 11, 12, Fe-rich rims on epidote (inset, see text), and the interpretation that the late retrograde domains (Fig. 6A) formed at lower temperatures than the early retrograde assemblage (Fig. 6B). ${ }^{40} \mathrm{Ar}-{ }^{39} \mathrm{Ar}$ closure temperatures are after Harrison (1981, hornblende), Hames \& Bowring (1994, muscovite), and Harrison et al. (1985, biotite), with schematic $\pm 25^{\circ} \mathrm{C}$ ranges to illustrate uncertainty and variation with cooling rate. Epidote $\mathrm{Fe}^{3+}$ per formula unit isopleths are the average of all nine samples, smoothed using a 3-point $\left(6^{\circ} \mathrm{C}\right)$ running average along the temperature axis.

also been described elsewhere (e.g., Little et al., 1995; Wells et al., 2005; Souche et al., 2013).

This metamorphic sequence, with the bulk of prograde mineral growth having taken place near the base of the Lower Allochthon against the hotter, deeply exhumed Middle Allochthon (metamorphic episode 4), is inferred to have occurred during early phases of extensional detachment, and continued during extension and unroofing (decompression path, Fig. 14) into the latest phase where both upper and lower plates of the detachment were subjected to subhorizontal extension and sinistral shear (cooling path, Fig. 14). Deformation during late extension formed veins in which precipitated the early retrograde assemblage (sample 386; Figs. 6B, 14). Locally along the detachment contact on Bolsøy, Robinson (1995) reported fine-grained mylonitic marbles with unrecovered calcite deformation fabrics, probably implying temperatures $<400^{\circ} \mathrm{C}$. These features may have formed coevally with the early retrograde vein assemblage reported here (Figs. 6B, 12, 14). Finally, thin brittle fractures allowed fluids to fill void space, and to replace minor amounts of prograde minerals with late retrograde albite, calcite, chlorite, spongy Fe-poor epidote, and fine-grained actinolite. 


\section{Conclusions}

The Upper Allochthon of Mid Norway, taken collectively, records a four-part metamorphic and deformational history: Early Ordovician (1), Mid to Late Ordovician (2), Silurian and earliest Devonian (3, Fig. 13A), and late Early Devonian (4, Fig. 13B). The metamorphosed cumulate gabbros studied here, however, seem to provide good evidence only for the last.

Because of complex mineral zoning and textures developed during different stages of metamorphism, it is not always easy to decide, using petrographic observations alone, which parts of one phase formed at the same time as, or in close equilibrium with, parts of other phases. In such rocks, traditional geothermometers and geobarometers are not always immediately useful. Instead, thermobarometric calculations can be used iteratively to help revise petrologic interpretations of complex rocks, ideally obtaining consistent results among multiple samples. Prograde regional metamorphism is often thought of as taking place during the height of orogenic activity: the time of crustal thickening and thrust faulting. Contact metamorphism is commonly thought of as occurring during pluton emplacement. Contact metamorphism related to detachment faulting late in orogen development, as a low-grade upper plate is brought into contact with a once deeper, hotter lower plate, is probably more common than is generally appreciated.

Acknowledgements. We thank Bradley Hacker, Jo Laird, Max Schmidt, John Schumacher, Bjørn Eske Sørensen, Jenny Thompson, and one anonymous reviewer for their helpful reviews of earlier versions of this manuscript. Field work of Kurt Hollocher was supported by Union College and the Norwegian Marshall Fund, and field work of Peter Robinson was supported by the Geological Survey of Norway. Wholerock chemical analyses of Kurt Hollocher were supported by Union College. The National Science Foundation supported instrumentation used for microbeam analyses (MRI-0619578).

\section{References}

Andersen, T.B. 1998: Extensional tectonics in the Caledonides of southern Norway, an overview. Tectonophysics 285, 333-351.

Andréasson, P.-G. \& Gorbatschev, R. 1980: Metamorphism in extensive nappe terrains: a study of the central Scandinavian Caledonides. Geologiska Föreningens $i$ Stockholm Förhandlingar 102, 335-357.

Andréasson, P.-G. \& Albrecht, L. 1995: Derivation of 500 Ma eclogites from the passive margin of Baltica and a note on the tectonometamorphic heterogeneity of eclogite-bearing crust. Geological Magazine 132, 729-738.

Andreásson, P.-G. \& Gee, D.G. 2008: The Baltica-Iapetus boundary in the Scandinavian Caledonides and a revision of the Middle and Upper Allochthons. 33 ${ }^{\text {rd }}$ International Geological Congress, 6-14 August 2008, Oslo, Norway, EUR06601L.

Armbruster, T., Bonazzi, P., Akasaka, M., Bermanec, V., Chopin, C., Giere, R., Heuss-Assbichler, S., Liebscher, A., Menchetti, S., Pan, Y. \& Pasero, M. 2006: Recommended nomenclature of epidote-group minerals. European Journal of Mineralogy 18, 551-567.

Barnes, C.G., Frost, C.D., Yoshinobu, A.S., McArthur, K., Barnes, M.A.,
Allan, C.M., Nordgulen, Ø. \& Prestvik, T. 2007: Timing of sedimentation, metamorphism, and plutonism in the Helgeland Nappe Complex, north-central Norwegian Caledonides. Geosphere 3, 683-703.

Benisek, A., Dachs, E. \& Kroll, H. 2010: A ternary feldspar-mixing model based on calorimetric data: Development and application. Contributions to Mineralogy and Petrology 160,327-337.

Bingen, B. \& Solli, A. 2009: Geochronology of magmatism in the Caledonian and Sveconorwegian belts of Baltica: Synopsis for detrital zircon provenance studies. Norwegian Journal of Geology $89,267-290$.

Bjerkgård, T. \& Bjørlykke, A. 1994: The stratabound sulphide deposits in the Folladal area, Southern Trondheim Region, Norway. Norsk Geologisk Tidsskrift 74, 213-237.

Brady, J.B. 1974: Coexisting actinolite and hornblende from westcentral New Hampshire. American Mineralogist 59, 529-535.

Bryhni, I. \& Andréasson, P.-G. 1985: Metamorphism in the Scandinavian Caledonides. In Gee, D.G. \& Sturt, B.A. (eds.): The Caledonide Orogen-Scandinavia and Related Areas, Part 1, John Wiley \& Sons, Inc., pp. 763-781.

Chauvet, A., Kienast, J.R., Pinardon, J.L. \& Burnel, M. 1992: Petrological constraints and PT path of Devonian collapse tectonics within the Scandian mountain belt (Western Gneiss Region, Norway: Journal of the Geological Society of London 149, 383-400.

Choudhuri, A. 1974: Distribution of Fe and Mg in actinolite, hornblende, and biotite in some Precambrian metagraywackes from Guyana, South America. Contributions to Mineralogy and Petrology 44, 45-55.

Connolly, J.A.D. 2009: The geodynamic equation of state: What and how. Geochemistry, Geophysics, Geosystems 10, Q10014, doi:10.1029/2009GC002540.

Çubukçu, H.E., Ersoy, O., Aydar, E. \& Çakir, U. 2008: WDS versus silicon drift detector EDS: A case report for the comparison of quantitative chemical analyses of natural silicate minerals. Micron 39, 88-94.

Cuthbert, S.J., Carswell, D.A., Krogh-Ravna, E.J. \& Wain, A. 2000: Eclogites and eclogites in the Western Gneiss Region, Norwegian Caledonides. Lithos 52, 165-195.

Dallmeyer, R.D. 1990: ${ }^{40} \mathrm{Ar} /{ }^{39} \mathrm{Ar}$ mineral age record of a polyorogenic evolution within the Seve and Köli nappes, Trøndelag, Norway. Tectonophysics 179, 199-226.

Dallmeyer, R.D. \& Gee, D.G. 1988: Polyorogenic ${ }^{40} \mathrm{Ar} /{ }^{39} \mathrm{Ar}$ mineral age record in the Seve and Köli Nappes of the Gäddede area, northwestern Jämtland, central Scandinavian Caledonides. Journal of Geo$\log y$ 96, 181-198.

Dallmeyer, R.D., Gee, D.G. \& Beckholmen, M. 1985: ${ }^{40} \mathrm{Ar} /{ }^{39} \mathrm{Ar}$ mineral age record of early Caledonian tectonothermal activity in the Baltoscandian miogeocline, central Scandinavia. American Journal of Science 285, 532-568.

Diener, J.F.A. \& Powell, R. 2011: Revised activity-composition models for clinopyroxene and amphibole. Journal of Metamorphic Geology 30, 131-142.

Eide, E.A. \& Lardeaux, J.M. 2002: A relict blueschist in meta-ophiolite from the central Norwegian Caledonides-Discovery and consequences. Lithos 60, 1-19.

Furnes, H., Pedersen, R.B. \& Stillman, C.J. 1988: The Leka Ophiolite Complex, central Norwegian Caledonides: Field characteristics and geotectonic significance. Journal of the Geological Society of London $145,401-412$.

Gee, D.G. 1975: A tectonic model for the central part of the Scandinavian Caledonides. American Journal of Science 275A, 468-515.

Gee, D.G. 2005: Scandinavian Caledonides (with Greenland). In Selley, R.C., Cocks, L.R.M. \& Plimer, I.R. (eds.): Encyclopedia of Geology, v. 2, Elsevier, Oxford, England, pp. 64-74.

Gee, D.G., Guezou, J.-C., Roberts, D. \& Wolff, F.C. 1985: The centralsouthern part of the Scandinavian Caledonides. In Gee, D.G. \& Sturt, B.A. (eds.): The Caledonide Orogen-Scandinavia and Related Areas, Part 2, John Wiley \& Sons, Inc., pp. 109-133. 
Gee, D.G., Fossen, H., Henriksen, N. \& Higgins, A.K. 2008: From the Early Paleozoic Platforms of Baltica and Laurentia to the Caledonide Orogen of Scandinavia and Greenland. Episodes 31, 44-51.

Grapes, R.G. 1975: Actinolite-hornblende pairs in metamorphosed gabbros, Hidaka Mountains, Hokkaido. Contributions to Mineralogy and Petrology 49, 125-140.

Grapes, R.M. \& Hoskin, P.W.O. 2004: Epidote group minerals in lowmedium pressure metamorphic terranes. In Liebscher, A. \& Franz, G. (eds.): Epidotes, Reviews in Mineralogy and Geochemistry, v. 56, Mineralogical Society of America, pp. 301-346.

Grenne, T. 1989: The feeder zone to the Løkken ophiolite-hosted massive sulfide deposit and related mineralizations in the central Norwegian Caledonides. Economic Geology 84, 2173-2195.

Grenne, T. \& Roberts, D. 1980: Geochemistry and volcanic setting of the Ordovician Forbordfjell and Jonsvatn greenstones, Trondheim region, central Norwegian Caledonides. Contributions to Mineralogy and Petrology 74, 375-386.

Grenne, T. \& Lagerblad, B. 1985: The Fundsjø Group, central Norwaya Lower Paleozoic island arc sequence: Geochemistry and regional implications. In Gee, D.G. \& Sturt, B.A. (eds.): The Caledonide Orogen-Scandinavia and Related Areas, Part 2, John Wiley \& Sons, Inc., pp. $745-760$.

Grenne, T., Grammeltvedt, G. \& Vokes, F.M. 1980: Cyprus-type sulphide deposits in the western Trondheim District, central Norwegian Caledonides. Cyprus-type sulphide deposits in the western Trondheim District, central Norwegian Caledonides. In Panayiotou, A. (ed.): Proceedings of the International Ophiolite Symposium, Cyprus, 1979, Cyprus Geological Survey, Nicosia, pp. 727-743.

Hacker, B.R. \& Gans, P.B. 2005: Continental collisions and the creation of ultrahigh-pressure terranes: Petrology and thermochronology of nappes in the central Scandinavian Caledonides. Geological Society of America Bulletin 117, 117-134.

Hames, W.E. \& Bowring, S.A. 1994: An empirical evaluation of the argon diffusion geometry in muscovite. Earth and Planetary Science Letters 124, 161-169.

Harper, D.A.T., Bruton, D.L. \& Rasmussen, C.M.Ø. 2008: The Otta brachiopod and trilobite fauna: palaeogeography of Early Palaeozoic terranes and biotas across Baltoscandian. Fossils and Strata 54, 31-40.

Harrison, T.M. 1981: Diffusion of ${ }^{40} \mathrm{Ar}$ in hornblende. Contributions to Mineralogy and Petrology 78, 324-331.

Harrison, T.M., Duncan, I. \& McDougall, I. 1985: Diffusion of ${ }^{40} \mathrm{Ar}$ in biotite: temperature, pressure and compositional effects. Geochimica et Cosmochimica Acta 49, 2461-2468.

Heim, M., Grenne, T. \& Prestvik, T. 1987: The Resfjell ophiolite fragment, southwest Trondheim region, central Norwegian Caledonides. Norges geologiske undersøkelse Bulletin 409, 49-71.

Holland, T.J.B. \& Powell, R. 1991: A Compensated Redlich-Kwong equation for volumes and fugacities of $\mathrm{CO}_{2}$ and $\mathrm{H}_{2} \mathrm{O}$ in the range $1 \mathrm{bar}$ to $50 \mathrm{kbar}$ and $100-1600^{\circ} \mathrm{C}$. Contributions to Mineralogy and Petrology 109, 265-273.

Holland, T. \& Blundy, J. 1994: Non-ideal interactions in calcic amphiboles and their bearing on amphibole-plagioclase thermometry. Contributions to Mineralogy and Petrology 116, 433-447.

Holland, T.J.B. \& Powell, R. 1996: Thermodynamics of order-disorder in minerals. 2. Symmetric formalism applied to solid solutions. American Mineralogist 81, 1425-1437.

Holland, T.J.B. \& Powell, R. 1998: An internally consistent thermodynamic data set for phases of petrological interest. Journal of Metamorphic Geology 16, 309-343.

Hollocher, K., Robinson, P., Walsh, E. \& Roberts, D. 2012: Geochemistry of amphibolite facies volcanics of the Støren Nappe in extensions southwest and west from the Trondheim region, western Gneiss Region, Norway: A key to correlations and paleotectonic settings. American Journal of Science 312, 357-416.

Klein, C., Jr. 1969: Two-amphibole assemblages in the system actinolite-hornblende-glaucophane. American Mineralogist 54, 212-237.
Krill, A.G. 1985: Relationships between the Western Gneiss Region and the Trondheim Region: Stockwerk-tectonics reconsidered. In Gee, D.G. \& Sturt, B.A. (eds.): The Caledonide Orogen-Scandinavia and Related Areas, Part 1, John Wiley \& Sons, Inc., pp. 475-483.

Krogh, T.E., Kamo, S.L., Robinson, P., Terry, M.P. \& Kwok, K. 2011: U$\mathrm{Pb}$ zircon geochronology of eclogites from the Scandian Orogen, northern Western Gneiss Region, Norway: 14-20 million years between eclogite crystallization and return to amphibolite facies conditions. Canadian Journal of Earth Sciences 48, 441-472.

Leake, B.E., Woolley, A.R., Arps, C.E.S., Birch, W.D., Gilbert, M.C., Grice, J.D., Hawthrone, F.C., Kato, A., Kisch, H.J., Krivovischev, V.G., Linthout, K., Laird, J., Mandarino, J.A., Maresch, W.V., Nickel, E.H., Rock, N.M.S., Schumacher, J.C., Smith, D.C., Stephenson, N.C.N., Ungaretti, L., Whittaker, E.J.W. \& Youzhi, G. 1997: Nomenclature of amphiboles: Report of the subcommittee on amphiboles on the International Mineralogical Association, Commission on new minerals and mineral names. American Mineralogist 82, 1019-1037.

Lindqvist, J.-E. \& Andréasson, P.-G. 1987: Illite crystallinity and prograde metamorphism in thrust zones of the Scandinavian Caledonides. Sciences Géologiques Bulletin 40, 217-230.

Little, T.A., McWilliams, M.O. \& Holcombe, R.J. 1995: ${ }^{40} \mathrm{Ar} /{ }^{39} \mathrm{Ar}$ thermochronology of epidote blueschists from the North D'Aguilar block, Queensland, Australia: Timing and kinematics of subduction complex unroofing. Geological Society of America Bulletin 107, 520-535.

McClellan, E.A. 2004: Metamorphic conditions across the Seve-Köli Nappe boundary, southeastern Trondheim region, Norwegian Caledonides: Comparison of garnet-biotite thermometry and amphibole chemistry. Norwegian Journal of Geology 84, 257-282.

Newbury, D.E. \& Ritchie, W.M. 2011: Is Scanning Electron Microscopy/Energy Dispersive X-ray Spectrometry (SEM/EDS) Quantitative? Effects of Specimen Shape. In Postek, M.T., Newbury, D.E., Platek, S.F., Joy, D.C. \& Maugel, T.K. (eds.): Scanning Microscopies 2011: Advanced Microscopy Technologies for Defense, Homeland Security, Forensic, Life, Environmental, and Industrial Sciences. Proceedings, SPIE, 803602, pp. 1-16.

Nilsen, O., Sundvoll, B., Roberts, D. \& Corfu, F. 2003: U-Pb geochronology and geochemistry of trondhjemites and a norite pluton from the SW Trondheim Region, Central Norwegian Caledonides. Norges geologiske undersøkelse Bulletin 441, 5-16.

Nilsen, O., Corfu, F. \& Roberts, D. 2007: Silurian gabbro-diorite-trondhjemite plutons in the Trondheim Nappe Complex, Caledonides, Norway: Petrology and $\mathrm{U}-\mathrm{Pb}$ geochronology. Norwegian Journal of Geology 87, 329-342.

Osmundsen, P.T., Eide, E.A., Haabesland, N.E., Roberts, D., Andersen, T.B., Kendrick, M., Bingen, B., Braathen, A. \& Redfield, T.F. 2006: Kinematics of the Høybakken detachment zone and the MøreTrøndelag Fault Complex, central Norway. Journal of the Geological Society, London 163, 303-318.

Pannemans, B. \& Roberts, D. 2000: Geochemistry and petrogenesis of trondhjemites and granodiorite from Gauldalen, central Norwegian Caledonides. Norges geologiske undersøkelse Bulletin $437,43-56$

Pedersen, R.B., Bruton, D.L., \& Furnes, H. 1992: Ordovician faunas, island arcs and ophiolites in the Scandinavian Caledonides. Terra Nova 4, 217-222.

Peterman, E.M., Hacker, B.R. \& Baxter, E.F. 2009: Phase transformations of continental crust during subduction and exhumation: Western Gneiss Region, Norway. European Journal of Mineralogy 21, 1097-1118.

Roberts, D. 1982: Disparate geochemical patterns from the Snåsavatn greenstone, Nord Trøndelag, central Norway. Norges geologiske undersøkelse Bulletin 373, 63-73.

Roberts, D. 1987: Geochemistry and Rb-Sr dating of the Muruvik rhyolite tuff, Trondheimsfjord, central Norway. Norges geologiske undersøkelse Bulletin 412, 43-53.

Roberts, D. 2003: The Scandinavian Caledonides: Event chronology, 
palaeogeographic settings and likely modern analogues. Tectonophysics 395, 283-299.

Roberts, D. \& Tucker, R.D. 1998: Late Cambrian U-Pb zircon age of a meta-trondhjemite from Ytterøya, Trondheimsfjorden, Central Norwegian Caledonides. Norsk Geologisk Tidsskrift 78, 253-258.

Roberts, D., Grenne, T. \& Ryan, P.D. 1984: Ordovician marginal basin development in the central Norwegian Caledonides. In Kokelaar, B.P. \& Howells, M.F. (eds.): Marginal basin geology, Geological Society of London, Special Publication 16, pp. 233-244.

Roberts, D., Sturt, B.A. \& Furnes, H. 1985: Volcanite assemblages and environments in the Scandinavian Caledonides and the sequential development history of the mountain belt. In Gee, D.G. \& Sturt, B.A. (eds.): The Caledonide Orogen-Scandinavia and related areas, Part 1, John Wiley \& Sons, Inc., pp. 919-930.

Roberts, D., Walker, N., Slagstad, T., Solli, A. \& Krill, A.G. 2002: U-Pb zircon ages from the Bymarka ophiolite, near Trondheim, central Norwegian Caledonides, and regional implications. Norsk Geologisk Tidsskrift 82, 19-30.

Roberts, D., Nordgulen, Ø. \& Melezhik, V. 2007: The Uppermost Allochthon in the Scandinavian Caledonides: From a Laurentian ancestry through Taconian orogeny to Scandian crustal growth on Baltica. In Hatcher, R.D. Jr., Carlson, M.P., McBride, J.H. \& MartInez Catalan, J.R. (eds.): 4-D Framework of Continental Crust, Geological Society of America Memoir 200, pp. 357-377.

Robinson, P. 1995: Extension of Trollheimen tectono-stratigraphic sequence in deep synclines near Molde and Brattvåg, Western Gneiss Region, southern Norway. Norsk Geologisk Tidsskrift 75, 181-198.

Robinson, P. \& Jaffe, H.W. 1969: Chemographic exploration of amphibole assemblages from central Massachusetts and southwestern New Hampshire. In Papike, J.J. (ed.): Pyroxenes and Amphiboles: Crystal Chemistry and Phase Petrology. Mineralogical Society of America, Special Paper 2, pp. 251-274.

Robinson, P., Spear, F.S., Schumacher, J.G., Laird, J., Klein, C., Evans, B.W. \& Doolan, B.L. 1982: Phase relations of metamorphic amphiboles: Natural occurrence and theory. In Veblen, D.R. \& Ribbe, P.H. (eds.): Amphiboles: Petrology and Experimental Phase Relations, Reviews in Mineralogy 9B, Mineralogical Society of America, Washington, D.C., pp. 1-227.

Robinson, P., Tucker, R.D., Solli, A., Terry, M.P., Krogh, T.E., Gee, D.G. \& Nordgulen, O. 2004: Scandian thrusting and extension in the Western Gneiss Region, Sør Trøndelag and Møre og Romsdal, Norway. Geologiska Föreningens i Stockholm Förhandlingar 126, Part 1, p. 84.

Robinson, P., Solli, A., Hollocher, K., Osmundsen, P.T., Roberts, D. \& Tucker, R.D. 2008: Day 5: Scandian geology of the outer Trondheimsfjord region. In Robinson, P., Roberts, D. \& Gee, D.G. (eds.): A tectonostratigraphic transect across the Central Scandinavian Caledonides, Part II, field preliminary trip guidebook. $33^{\text {rd }}$, Norges geologiske undersøkelse Report 2008.064, pp. 5-1 - 5-37.

Robinson, P., Roberts, D., Gee, D.G. \& Solli, A. 2014: A major synmetamorphic Early Devonian thrust and extensional fault system in the Mid Norway Caledonides: relevance to exhumation of HP and UHP rocks. In Corfu, F., Gasser, D. \& Chew, D.M. (eds.): New Perspectives on the Caledonides of Scandinavia and Related Areas. Geological Society, London, Special Publication 390, pp. 241-270.

Root, D.B., Hacker, B.R., Gans, P.B., Ducea, M.N., Eide, E.A. \& Mosenfelder, J.L. 2005: Discrete ultrahigh-pressure domains in the Western Gneiss Region, Norway: Implications for formation and exhumation. Journal of Metamorphic Geology 23, 45-61.

Schumacher, J.C. 1991: Empirical ferric iron corrections: Necessity, assumptions, and effects on selected geothermobarometers. Mineralogical Magazine 55, 3-18.

Schumacher, R. 1991: Compositions and phase relations of calcic amphiboles in epidote- and clinopyroxene-bearing rocks of the amphibolite and lower granulite facies, central Massachusetts, USA. Contributions to Mineralogy and Petrology 108, 196-211.
Schumacher, J.C. 2007: Metamorphic amphiboles: Composition and coexistence. In Hawthorne, F.C., Oberti, R., Della Ventura, G. \& Mottana, A. (eds.): Amphiboles: Crystal Chemistry, Occurrence, and Health Issues, Reviews in Mineralogy and Petrology 67, Mineralogical Society of America, pp. 359-416.

Semelik, E.A., Nyman, M.W. \& Veblen, D.R. 1991: Pervasive exsolution within the calcic amphibole series: TEM evidence for a miscibility gap between actinolite and hornblende in natural samples. American Mineralogist 76, 1184-1204.

Souche, A., Dabrowski, M. \& Andersen, T.B. 2013: Modeling thermal convection in supradetachment basins: example from western Norway. Geofluids 14, 58-74.

Spencer, K.J., Hacker, B.R., Kylander-Clark, A.R.C., Andersen, T.B., Cottle, J.M., Stearns, M.A., Poletti, J.E. \& Seward, G.G.E. 2012: Campaign-style titanite $\mathrm{U}-\mathrm{Pb}$ dating by laser-ablation ICP: Implications for crustal flow, phase transformations and titanite closure. Chemical Geology 341, 84-101.

Stephens, M.B. \& Gee, D.G. 1985: A tectonic model for the evolution of the eugeoclinal terranes in the central Scandinavian Caledonides. In Gee, D.G. \& Sturt, B.A. (eds.): The Caledonide orogenScandinavia and related areas, John Wiley \& Sons, Inc., pp. 953-978.

Sturt, B.A. \& Roberts, D. 1991: Tectonostratigraphic relationships and obduction histories of Scandinavian ophiolitic terranes. In Peters, T.J., Nicolas, A. \& Coleman, R. (eds.): Ophiolite genesis and evolution of the ocean lithosphere. Ministry of Petroleum \& Minerals, Sultanate of Oman, pp. 745-769.

Terry, M.P. \& Robinson, P. 2003: Evolution of amphibolite facies structural features and boundary conditions for deformation during exhumation of high- and ultrahigh-pressure rocks, Nordøyane, Western Gneiss Region, Norway. Tectonics 22, 10-1 10-23, doi:10.1029/2001TC001349, 4.

Terry, M.P., Robinson, P. \& Krogh Ravna, E.J. 2000: Kyanite eclogite thermobarometry and evidence for thrusting of UHP over HP metamorphic rocks, Nordøyane, Western Gneiss Region, Norway. American Mineralogist 85, 1673-1650.

Tucker, R.D., Robinson, P., Solli, A., Gee, D.G., Thorsnes, T., Krogh, T.E., Nordgulen, $\varnothing$. \& Bickford, M.E. 2004: Thrusting and extension in the Scandian hinterland, Norway: New $\mathrm{U}-\mathrm{Pb}$ ages and tectonostratigraphic evidence. American Journal of Science 304, 477-532.

Vetti, V.V. \& Fossen, H. 2012: Origin of contrasting Devonian supradetachment basin types in the Scandinavian Caledonides. Geology 40, 571-574.

Walsh, E.O. \& Hacker, B.R. 2004: The fate of subducted continental margins: Two-stage exhumation of the high-pressure to ultrahighpressure Western Gneiss Region, Norway. Journal of Metamorphic Geology 22, 671-687.

Wells, M.L., M.A. Beyene, Spell, T.L., Kula, J.L., Miller, D.M. \& Zanetti, K.A. 2005: The Pinto shear zone; a Laramide synconvergent extensional shear zone in the Mojave Desert region of the southwestern United States. Journal of Structural Geology 27, 16971720.

White, R.W., Powell, R., Holland, T.J.B. \& Worley, B.A. 2000: The effect of $\mathrm{TiO}_{2}$ and $\mathrm{Fe}_{2} \mathrm{O}_{3}$ on metapelitic assemblages at greenschist and amphibolite facies conditions: Mineral equilibria calculations in the system $\mathrm{K} 2 \mathrm{O}-\mathrm{FeO}-\mathrm{MgO}-\mathrm{Al}_{2} \mathrm{O}_{3}-\mathrm{SiO}_{2}-\mathrm{H}_{2} \mathrm{O}-\mathrm{TiO}_{2}-\mathrm{Fe}_{2} \mathrm{O}_{3}$. Journal of Metamorphic Geology 18, 497-511. 


\section{Appendix 1: Microbeam analytical methods}

Microbeam analyses were collected from carbon-coated, polished thin-sections using a Zeiss EVO50XVP scanning electron microscope, in high-vacuum mode, with a tungsten filament electron source, and a probe current of 6 or 7 $\mathrm{nA}$ at an accelerating potential of $15 \mathrm{keV}$. X-ray data were collected with a Bruker XFlash 4010 silicon drift detector, cooled to $-25^{\circ} \mathrm{C}$, with a takeoff angle of $35^{\circ}$. The X-ray spectrum was calibrated over an energy range of $0.15-10$ $\mathrm{keV}$, a 0-60,000 counts per second pulse processing range, an actual count rate of $\sim 40,000 \mathrm{cps}$ on polished copper, and an energy resolution of $124 \mathrm{eV}$ for the Mn Ka1,2 peak. Sample Z-axis position (distance from lowermost beam magnet) was set to achieve maximum count rate. Analyses were acquired exclusively in spot mode at the center of the backscattered electron image field of view, to avoid differences in X-ray count rate at other beam locations. To maintain stable beam current, standardization and data acquisition were done without changing magnification or magnet-controlled focus. The X-ray system factor (integrated count rate, $0.15-10 \mathrm{keV}$, on polished copper) was periodically measured to adjust for beam current drift.

Standards used were augite (px69, U. Michigan, 15.92\% $\mathrm{MgO}, 51.02 \% \mathrm{SiO}_{2}, 21.27 \% \mathrm{CaO}, 3.92 \% \mathrm{FeO}$ ), labradorite (PG721, U. Massachusetts, Amherst, 4.95\% $\mathrm{Na}_{2} \mathrm{O}$, 28.51\% $\mathrm{Al}_{2} \mathrm{O}_{3}$ ), microcline (GKFS, U. Michigan, $14.71 \%$ $\mathrm{K}_{2} \mathrm{O}$ ), rhodonite (BHRH, U. Michigan, 32.18\% MnO), and rutile (Rut, Cannon Microprobe, Seattle, Washington, $98.76 \% \mathrm{TiO}_{2}$ ). Standard deviations, based on multiple analyses of different spots on the standards during different sessions, varied with concentration, from $0.1 \%$ for $\mathrm{FeO}$ on the augite standard to $0.57 \% \mathrm{TiO}_{2}$ on rutile.

Analytical data were processed in standards-based mode, with identical analytical conditions for both standards and unknowns. A total of $10^{6}$ counts $(0.15-10 \mathrm{keV})$ were acquired for each spectrum, which were processed using manual element selection, automatic physical background determination, series peak fitting, carbon coat correction, and standards-based Phi-Rho-Z correction. Totals, as oxides calculated from the metals (i.e., analyzed oxygen was ignored after the analyses were acquired), were generally within $1 \%$ of expected values. Detection limits were determined by analyzing a variety of standards with different element concentrations, and extrapolating analytical uncertainty to zero concentration. $2 \sigma$ detection limits ranged from about 0.05 wt.\% for Na to 0.1 wt.\% for Fe. Although detection limits are not so low as for wavelengthdispersive electron probes, most low-concentration elements ( $\mathrm{K}, \mathrm{Mn}$, and Ti) were discarded from the system compositions used for thermodynamic calculations because they are absent from the thermodynamic solution models. For higher concentration elements, particularly using modern silicon drift detectors, results for energy dispersive analyses have been shown to be comparable to electron probe analyses (e.g., Çubukçu et al., 2008; Newbury \& Ritche, 2011).

\section{Appendix 2: Thermodynamic modeling with PERPLE_X}

Perple_X version 6.6.6 (Connolly, 2009, and references therein) was used for all thermodynamic calculations, using the hp02ver.dat end member thermodynamic data set and the following solution models: cAmph(DP2) (clinoamphibole, Diener \& Powell, 2011), Cpx(HP) (clinopyroxene, Holland \& Powell, 1996), Ep(HP) (epidote, Holland \& Powell, 1998), feldspar_B (feldspar, Benisek et al., 2010), and $\operatorname{Ilm}(\mathrm{WPH})$ (ilmenite, White et al., 2000). Calculations were done in the $\mathrm{NaCaMgFeAlSiTiHO}$ system. $\mathrm{Fe}_{2} \mathrm{O}_{3}$ was added to the models as a transformed component: $\mathrm{Fe}_{2} \mathrm{O}_{3}=2 \mathrm{FeO}+$ $0.5 \mathrm{O}_{2}$. The end members ts, parg, gl, ilm, and ilm_nol were excluded because the amphibole and ilmenite solution models used their own equivalent end members. Also excluded were zo (end member zoisite) and ab (end member low albite) because these made the phase diagrams more complex, closely duplicated Fe-poor epidote and Na-rich plagioclase predicted by the solution models, and did not substantially affect the compositions or proportions of amphibole, diopside, total feldspar, or total epidote.

$\mathrm{H}_{2} \mathrm{O}$ fluid was added to all models as a saturated phase, with a $\mathrm{CO}_{2}$ fraction of zero and using the fluid equation of state of Holland \& Powell (1991, 1998). Trial models with $\mathrm{CO}_{2}$ in the fluid phase indicated that only a few percent $\mathrm{CO}_{2}$ stabilized calcite. Calcite was not present in the matrix in most samples, and in the rest calcite was restricted to sparse, narrow zones, possibly indicating that it was introduced after peak prograde metamorphic conditions. The early retrograde vein in sample 386 contained no visible calcite. We interpreted these observations to indicate that the fluid was overwhelmingly dominated by $\mathrm{H}_{2} \mathrm{O}$, at least during the peak prograde to early retrograde (vein filling) episodes. Small fractions of $\mathrm{CO}_{2}$ in the fluid phase would not have substantively affected the model silicate phase relations. 


\section{Appendix 3: \\ Preparing model system compositions}

\section{Model system compositions from mineral compositions}

Modeling for peak prograde and early retrograde metamorphic conditions used thermodynamic system compositions (Table 1) that were derived from mineral analyses. For these, appropriate individual or average mineral analyses were selected based on textural and compositional interpretation (see text). Mineral analyses, however, had to be modified to appropriately fit the thermodynamic solution models used for different phases.

1. The selected mineral compositions were first converted to cation proportions.

2. Because Mn, K, and Ti are not included or necessary in some solution models, these were removed from the mineral compositions as follows:

$\mathrm{Mn}$ from hornblende and diopside: $\mathrm{Mn}^{2+}{ }_{-1} \mathrm{Fe}^{2+}{ }_{1}(\mathrm{Mn}=\mathrm{Fe})$.

$\mathrm{K}$ from plagioclase: $\mathrm{K}_{-1} \mathrm{Al}_{-1} \mathrm{Si}_{-3}$ (K-feldspar).

$\mathrm{K}$ from hornblende: $\mathrm{K}_{-1} \mathrm{Al}_{-1}^{-1} \square_{1}^{-3} \mathrm{Si}_{1}$ (K-edenite).

$\mathrm{Ti}$ from hornblende and diopside: $\mathrm{Ti}_{-1} \mathrm{Al}_{-2}(\mathrm{Mg}, \mathrm{Fe})_{1} \mathrm{Si}_{2}$ ( $\mathrm{Mg}$ and $\mathrm{Fe}$ in the analyzed mineral molar proportions).

3. $\mathrm{Fe}^{3+}$ in amphiboles was calculated using the scheme of Holland \& Blundy (1994, see text).

4. All Fe in epidote was taken as $\mathrm{Fe}^{3+}$.

5. $\mathrm{Fe}^{3+}$ in diopside was taken as $0.05 \mathrm{Fe}_{\text {total }}$. This was approximately the average for all diopside analyses with $\mathrm{Fe}^{3+}$ calculated on a basis of 4 cations and 6 oxygens.

6. Cation proportions were changed to cations per formula unit, then the diopside, epidote, and plagioclase formulae were idealized to better fit the solution models as follows:

Diopside was normalized to a cation sum of 4 .

For epidote, $\mathrm{Si}$ and $\mathrm{Ca}$ were set to 3 and 2, respectively, and $\mathrm{Al}$ and $\mathrm{Fe}^{3+}$ normalized to a sum of 3 .

The plagioclase composition was recalculated by averaging the four equivalent anorthite component values: 1-Na, Al-1,3-Si, and Ca.

7. The idealized cation proportions were converted to oxide weights, and normalized to $99.99 \%$ sums for each mineral.

8. Oxide weights were combined in different proportions for the models (e.g., for peak prograde models the proportions were 30:30:30:10, amphibole, diopside, plagioclase, and epidote, respectively).

9. $0.01 \% \mathrm{TiO}_{2}$ was added to the system to monitor the stability of rutile, ilmenite, and titanite.
Model system compositions from whole-rock compositions

Model system compositions for early prograde conditions (Table 2) used whole-rock analyses. Because solution models for the major phases (amphibole, diopside, plagioclase, epidote) do not include some analyzed elements, the analyzed compositions were modified as follows (example in Table A1):

1. Whole-rock analyses were converted to element proportions

2. Unnecessary elements removed as follows:

$\mathrm{Mn}: \mathrm{Mn}^{2+}{ }_{1} \mathrm{Fe}^{2+}(\mathrm{Mn}=\mathrm{Fe})$.

$\mathrm{K}: \mathrm{K}_{-1} \mathrm{Al}_{-1} \mathrm{Si}_{-3}$ (K-feldspar).

$\mathrm{Ti}: \mathrm{Ca}_{-1} \mathrm{Ti}_{-1} \mathrm{Si}_{-1}$ (titanite).

$\mathrm{S}: \mathrm{Fe}_{-1} \mathrm{~S}_{-2}$ (pyrite).

C: $\mathrm{Ca}_{1-1} \mathrm{C}_{1}$ (calcite).

$\mathrm{P}: \mathrm{Ca}_{-5} \mathrm{P}_{-3}$ (apatite).

3. Fe was divided into $\mathrm{Fe}^{2+}$ and $\mathrm{Fe}^{3+}$ in the proportion 9:1.

4. The residual element proportions were recalculated back to weight percent of the oxides and normalized to $99.99 \%$

5. $0.01 \% \mathrm{TiO}_{2}$ was added back to monitor the stability of rutile, ilmenite, and titanite.

\begin{tabular}{|c|c|c|}
\hline Sample & Original analysis & Model composition \\
\hline $\mathrm{SiO}_{2}$ & 49.55 & 50.02 \\
\hline $\mathrm{TiO}_{2}$ & 0.39 & 0.01 \\
\hline $\mathrm{Al}_{2} \mathrm{O}_{3}$ & 15.56 & 15.81 \\
\hline $\mathrm{Fe}_{2} \mathrm{O}_{3}$ & - & 0.65 \\
\hline $\mathrm{FeO}$ & 5.67 & 5.27 \\
\hline $\mathrm{MnO}$ & 0.12 & - \\
\hline $\mathrm{MgO}$ & 11.21 & 11.43 \\
\hline $\mathrm{CaO}$ & 15.79 & 15.62 \\
\hline $\mathrm{Na}_{2} \mathrm{O}$ & 1.17 & 1.19 \\
\hline $\mathrm{K}_{2} \mathrm{O}$ & 0.06 & - \\
\hline $\mathrm{P}_{2} \mathrm{O}_{5}$ & 0.01 & - \\
\hline $\mathrm{CO}_{2}$ & 0.15 & - \\
\hline $\mathrm{S}$ & 0.05 & - \\
\hline Total & 99.73 & 100.00 \\
\hline
\end{tabular}

